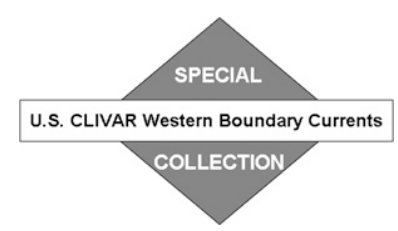

\title{
Atmospheric Response to the Gulf Stream: Seasonal Variations*
}

\author{
Shoshiro Minobe And Masato Miyashita \\ Department of Natural History Sciences, Graduate School of Science, Hokkaido University, Sapporo, Japan
}

AKIRA KUWANO-YOSHIDA

Earth Simulator Center, Japan Agency for Marine-Earth Science and Technology, Yokohama, Japan

Hiroki TokinAga And SHANG-PING XIE

International Pacific Research Center, and Department of Meteorology, University of Hawaii at Manoa, Honolulu, Hawaii

(Manuscript received 28 July 2009, in final form 29 January 2010)

\begin{abstract}
The atmospheric response to the Gulf Stream front in sea surface temperature is investigated using highresolution data from satellite observations and operational analysis and forecast. Two types of atmospheric response are observed with different seasonality and spatial distribution.

In winter, surface wind convergence is strong over the Gulf Stream proper between Cape Hatteras and the Great Banks, consistent with atmospheric pressure adjustments to sea surface temperature gradients. The surface convergence is accompanied by enhanced precipitation and the frequent occurrence of midlevel clouds. Local evaporation and precipitation are roughly in balance over the Florida Current and the western Gulf Stream proper. In summer, strong precipitation, enhanced high clouds, and increased lightning flash rate are observed over the Florida Current and the western Gulf Stream proper, without seasonal surface convergence enhancement. For the precipitation maximum over the Florida Current, local evaporation supplies about half of the water vapor, and additional moisture is transported from the south on the west flank of the North Atlantic subtropical high.

Atmospheric heating estimated by a Japanese reanalysis reveals distinct seasonal variations. In winter, a shallow-heating mode dominates the Gulf Stream proper, with strong sensible heating in the marine atmospheric boundary layer and latent heating in the lower troposphere. In summer, a deep-heating mode is pronounced over the Florida Current and the western Gulf Stream proper, characterized by latent heating in the middle and upper troposphere due to deep convection. Possible occurrences of these heating modes in other regions are discussed.
\end{abstract}

\section{Introduction}

How the midlatitude ocean influences the overlying atmosphere on climate time scales is a long-standing question. Namias $(1969,1972)$ hypothesized that anomalies of extratropical sea surface temperature (SST) cause

\footnotetext{
* International Pacific Research Center Publication Number 671 and School of Ocean and Earth Science and Technology Publication Number 7894.

Corresponding author address: Shoshiro Minobe, Department of Natural History Sciences, Graduate School of Science, Hokkaido University, N10 W8, Sapporo 060-0810, Japan.

E-mail: minobe@sci.hokudai.ac.jp
}

interannual and decadal persistency of atmospheric circulation anomalies. This basin-scale covariability between the atmosphere and ocean, however, is now generally recognized as being due to the atmospheric forcing onto the ocean via surface heat fluxes and Ekman currents in response to changes in surface wind speed, surface air temperature, and surface humidity (e.g., Namias 1959; Bjerknes 1964; Cayan 1992). Exceptions occur in regions of western boundary currents, such as the Gulf Stream and the Kuroshio, where SST anomalies are controlled by advection, resulting in a source of heat flux anomalies (Dong et al. 2007; Tanimoto et al. 2003). There is observational evidence that the midlatitude ocean, especially western boundary currents, influences the atmosphere (e.g., Czaja and Frankignoul 2002; Ciasto and Thompson 
2004; Watanabe et al. 2006). Observational studies, however, suffered from the short length of available data, insufficient to determine the contribution of ocean-toatmosphere influences, which can be masked by energetic atmosphere-to-ocean influences. Numerical studies of atmospheric responses to midlatitude SST anomalies, on the other hand, showed diverse results, probably because the effects of eddy-mean flow interactions induced by SST changes are different from one model to another (Kushnir et al. 2002). Also, even within the same model, the atmospheric response to given SST anomalies can be different with different background states (e.g., Peng et al. 1997). A recent study suggests that the different responses can be understood in terms of changes in the position of the midlatitude SST front relative to the subtropical jet (Brayshaw et al. 2008).

The Gulf Stream is the strongest western boundary current (Tomczak and Godfrey 2003). Its influences on weather variability have been studied extensively. Sanders (1986) showed that the most rapid deepening bomb cyclones tend to move along the axis of the Gulf Stream. Strong ocean-to-atmosphere turbulent heat flux is observed over the Gulf Stream (e.g., Doyle and Warner 1993; Zolina and Gulev 2003). Kuo et al. (1991) and Reed et al. (1993) demonstrated that latent heat release is important in cyclogenesis using regional atmospheric models. Mesoscale rainbands parallel to the Gulf Stream were frequently observed by coastal radar (Hobbs 1987; Trunk and Bosart 1990). Young and Sikora (2003) and Li et al. (2004) reported the Gulf Stream influences on cloud formation on weather time scales. However, the influence of the Gulf Stream and other ocean currents on the atmosphere on climate time scales was not well understood.

Recent observational and numerical studies showed that extratropical ocean fronts and mesoscale eddies ubiquitously influence the marine atmospheric boundary layer (MABL). In particular, unprecedented observations of surface winds by the Quick Scatterometer (QuikSCAT) satellite demonstrated that the wind divergence and wind curl exhibit coherent structures across ocean fronts or mesoscale ocean eddies (see reviews by Chelton et al. 2004; Xie 2004; Small et al. 2008). Such relations are globally observed for regions of strong SST gradients, that is, tropical instability waves (Liu et al. 2000), the Kuroshio in the East China Sea (Xie et al. 2002), the Kuroshio south of Japan (Nonaka and Xie 2003), the Kuroshio Extension (Tokinaga et al. 2009), the Gulf Stream (Chelton et al. 2004; Xie 2004; Minobe et al. 2008), the Agulhas Return Current (O'Neill et al. 2003, 2005), and the Brazil-Malvinas Currents (Tokinaga et al. 2005). Similar relations between surface winds and SSTs are widely observed over mesoscale ocean eddies (White and Annis 2003; Bourras et al. 2004; Park et al. 2006).
More recent studies showed evidence for atmospheric responses beyond MABL, in the free troposphere. Minobe et al. (2008) demonstrated that surface wind convergence, enhanced evaporation and rain, deep ascent in the midtroposphere, and frequent occurrences of high cloud tops appear just over the Gulf Stream current axis. Similarly, Tokinaga et al. (2009) reported tropospheric responses to the Kuroshio Extension east of Japan, characterized by enhanced precipitation, frequent cloud occurrence, enhanced lightning activity, and upward winds. The deep atmospheric influences of SST fronts are not limited to western boundary current regions. Kobashi et al. (2008) showed that the subtropical front in the western North Pacific induces a deep atmospheric response, and Liu et al. (2007) reported that the permanent meanders of the Agulhas Return Current affect tropospheric air temperature, cloud-top heights, and cloud thickness. These studies show that climatic influences of ocean currents and accompanied SST fronts extend much higher in the atmosphere than previously thought. Questions remain as to how such deep atmospheric influences vary seasonally, given that major SST fronts are located in the extratropics and experience large seasonal variations.

The purpose of the present paper is to describe the atmospheric response to the Gulf Stream in detail, especially with regard to its seasonality, using spatially high-resolution datasets. We show two distinct modes of atmospheric response with different seasonality. The rest of the present paper is organized as follows. Section 2 describes the data used in the present study. Section 3 discusses surface oceanic conditions of SSTs and surface currents as background information. Section 4 examines surface wind convergence and precipitation. Section 5 describes cloud and lightning. In section 6 , vertical winds and their relation to horizontal wind divergence are examined. Section 7 investigates atmospheric heating. Section 8 presents conclusions and a discussion.

\section{Data}

\section{a. Operational analysis and reanalysis data}

We use the monthly fields on a $0.5^{\circ} \times 0.5^{\circ}$ grid of operational analysis and the associated forecast fields provided by the European Centre for Medium-Range Weather Forecasts (ECMWF) from January 2002 to February 2006, the same period as in Minobe et al. (2008). The operational atmospheric model uses a spectral dynamical core with TL511 resolution (i.e., triangular truncation at total wavenumber 511 with a linear grid for spectral transforms), equivalent to a grid resolution of approximately $38 \mathrm{~km}$, from the beginning of the analysis period to January 2006. The last month of the analysis 
(a) DJF

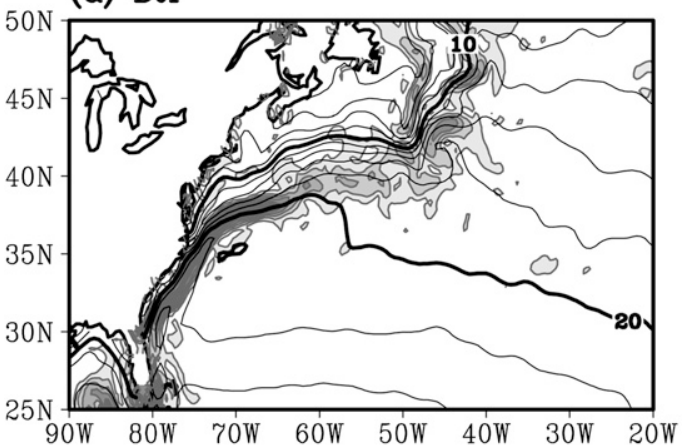

(c) JJA

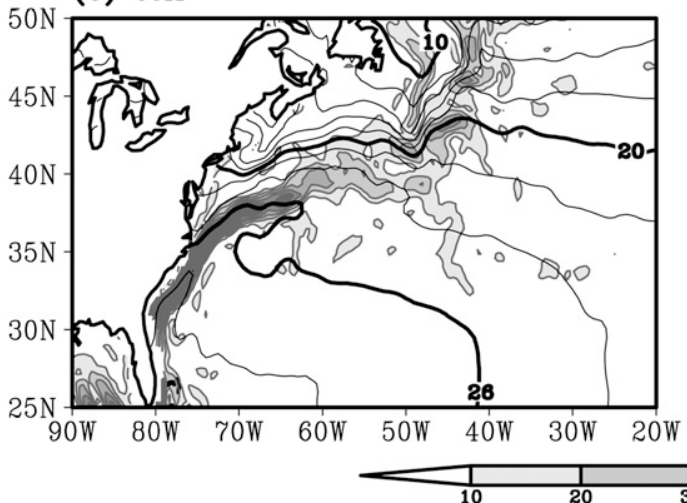

(b) MAM

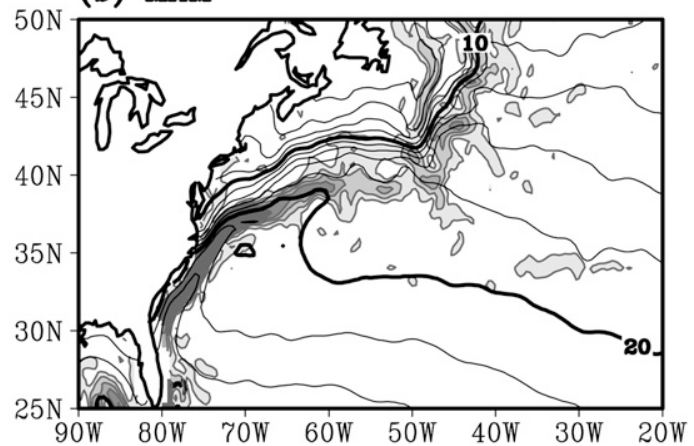

(d) SON

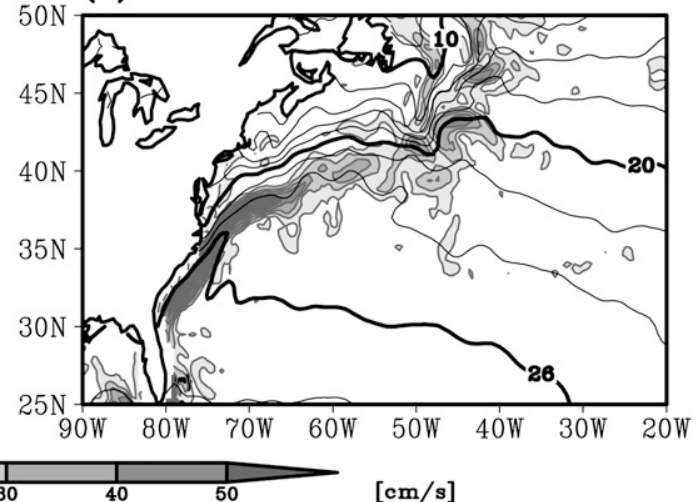

FIG. 1. Seasonal mean surface geostrophic current velocities (shading) and SSTs (contours). Contour interval is $2^{\circ} \mathrm{C}$ with thick contours at $10^{\circ}, 20^{\circ}$, and $26^{\circ} \mathrm{C}$.

period, February 2006, is analyzed with a TL799 model, equivalent to $25-\mathrm{km}$ resolution. The results with and without February 2006 are essentially the same. We describe the results including this month. During the analysis period, the ECMWF model uses the Real-Time, Global, SST (RTGSST) (Thiébaux et al. 2003), resulting in a much better representation of surface wind response to short-scale SST variations (Chelton and Wentz 2005). The analysis variables are 10-m zonal and meridional wind velocities, sea level pressure (SLP), SST, pressure vertical velocity, and the forecast variables are convective and large-scale precipitation, surface heat fluxes, and boundary layer height, which are not provided in the operational analysis. The 24-h forecast values are described in the present paper, but those from a 12-h forecast give almost identical results. Consistency between the analysis and forecast fields is confirmed by the fact that the analysis SLP is virtually the same as the 24-h forecast SLP

We use the monthly fields of vertically integrated moisture fluxes and three-dimensional atmospheric heating rate from the Japanese 25-year Reanalysis Project (JRA-25) (Onogi et al. 2007) produced jointly by the Japan Meteorological Agency (JMA) and the Central
Research Institute of Electric Power Industry. These fields are available on a $1.25^{\circ} \times 1.25^{\circ}$ grid and 40 vertical levels from 1979 to 2004 . The product is updated for the subsequent period using the same climatic assimilation system called the JMA Climate Data Assimilation System (JCDAS). We analyze the JRA-25/JCDAS for the study period from January 2002 to February 2006, limited by the ECMWF data available to us.

\section{b. Satellite data}

We analyze a suite of satellite observations of sea surface wind, cloud fraction, lightning flash frequency as well as sea surface height. Our study period is, again, from January 2002 to February 2006 unless otherwise stated. The Atmospheric Infrared Sounder (AIRS) and the Advanced Microwave Sounding Unit (AMSU) aboard the National Aeronautics and Space Administration (NASA) Aqua spacecraft, launched in May 2002, measure atmospheric temperature and humidity under both clear and cloudy conditions (Aumann et al. 2003). We use the AIRS/ AMSU level-3 monthly mean product (version 5) of cloud fractions on a $1^{\circ} \times 1^{\circ}$ grid from the beginning of the data (September 2002) to February 2006, available at the NASA Goddard Earth Sciences (GES) Data 
(a) DJF

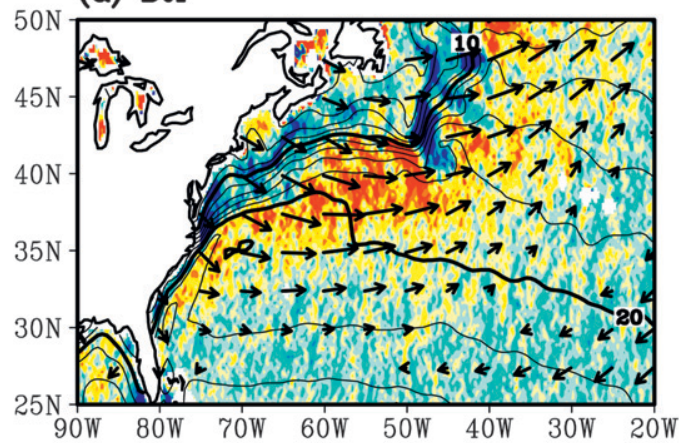

(c) JJA

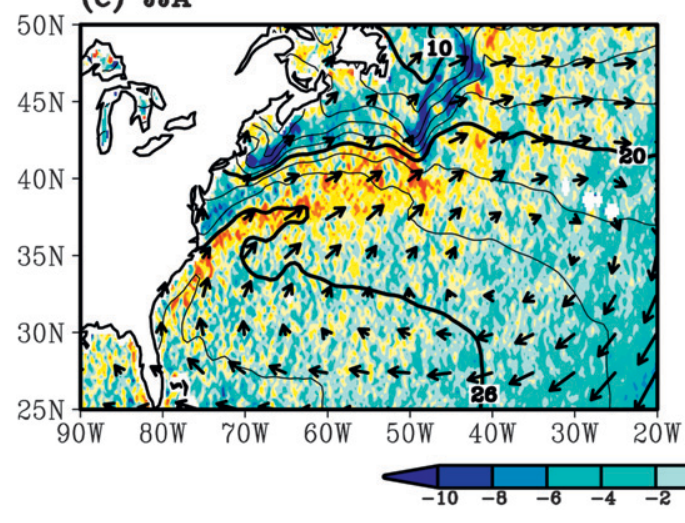

(b) MAM

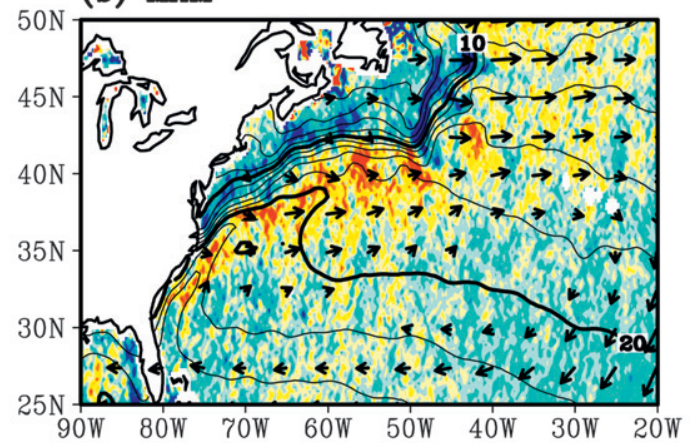

(d) SON

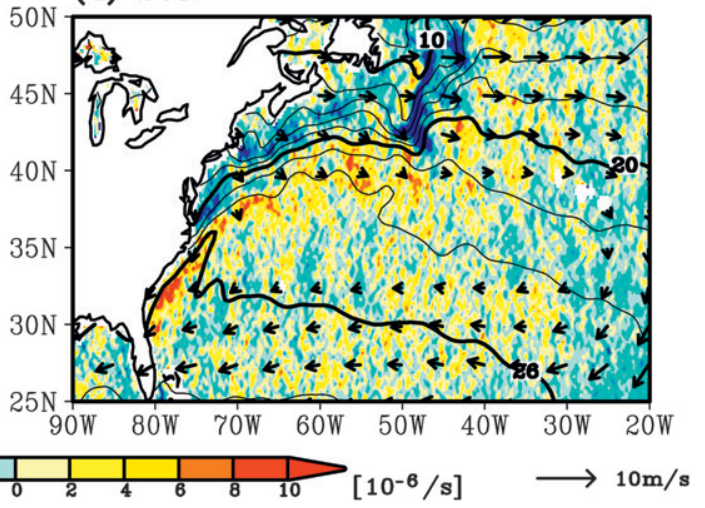

FIG. 2. Seasonal mean near-surface wind velocities (vectors) and their convergences (color) observed by QuikSCAT and SSTs (contours). Contour interval of SSTs are $2^{\circ} \mathrm{C}$, with thick contours of $10^{\circ}, 20^{\circ}$, and $26^{\circ} \mathrm{C}$.

Information and Services Center (DISC). There are two cloud fraction products: one has coarse vertical resolution (low-, mid-, and upper-level cloud fractions) and the other has a fine vertical resolution of 12 levels. For simplicity, we mainly use the coarse vertical resolution product.

For precipitation, we use the Tropical Rainfall Measuring Mission (TRMM) 3B43 product, derived from TRMM and other satellite observations: geosynchronous infrared radiometer, Special Sensor Microwave Imager (SSM/I), rain gauge, and the TRMM 3B31 product based on the TRMM precipitation radar and microwave imager on a monthly $0.25^{\circ} \times 0.25^{\circ}$ grid between $50^{\circ} \mathrm{S}$ and $50^{\circ} \mathrm{N}$. The TRMM $3 \mathrm{~B} 43$ product is available at the Goddard Earth Sciences Data and Information Services Center.

The microwave scatterometer SeaWinds on the NASA QuikSCAT satellite measures daily surface wind velocity over the global ocean. It has revealed rich wind structures on short spatial scales around the world (Chelton et al. 2004; Xie 2004; Sampe and Xie 2007; Joyce et al. 2009). We use monthly wind velocity calculated from the twicedaily equivalent neutral wind at $10 \mathrm{~m}$ available from Remote Sensing Systems (RSS) on a $0.25^{\circ} \times 0.25^{\circ}$ grid. The equivalent neutral wind is the $10-\mathrm{m}$ wind that would be associated with the surface stress observed by scatterometer, if the atmospheric boundary layer were neutrally stratified (Liu and Tang 1996). The difference between the equivalent neutral wind and actual wind was estimated to be about $0.2 \mathrm{~m} \mathrm{~s}^{-1}$ (Chelton and Freilich 2005).

As an indicator of atmospheric convective activity, we use the monthly climatology of lightning activity observed by the Optical Transient Detector (OTD) onboard the MicroLab-1 satellite from April 1995 to March 2000 and the Lightning Imaging Sensor (LIS) onboard the TRMM satellite from January 1998 to December 2005. Using OTD data, Christian et al. (2003) have reported high lightning activity in the North Atlantic and western North Pacific Oceans year-round, with atmospheric convection produced as cold air blows over a warm ocean surface. The LIS/OTD merged monthly climatology is available at the NASA Global Hydrology Resource Center on a $0.5^{\circ} \times 0.5^{\circ}$ grid.

Sea surface geostrophic currents are estimated from satellite altimetry data and the mean dynamic topography, obtained from Archiving, Validation, and Interpretation of Satellite Oceanographic data (AVISO). The satellite altimetry data combine measurements from the Ocean Topography Experiment (TOPEX)/Poseidon, ERS-1/2, Jason-1, and Envisat satellites (Ducet and Le Traon 2001), while the mean dynamic topography is 
(a) DJF

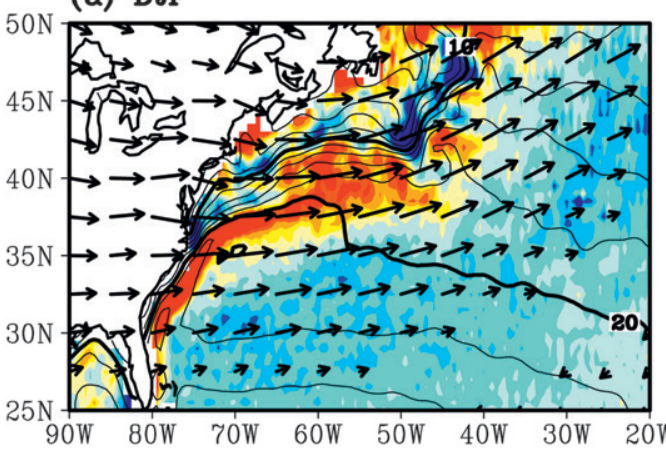

(c) JJA

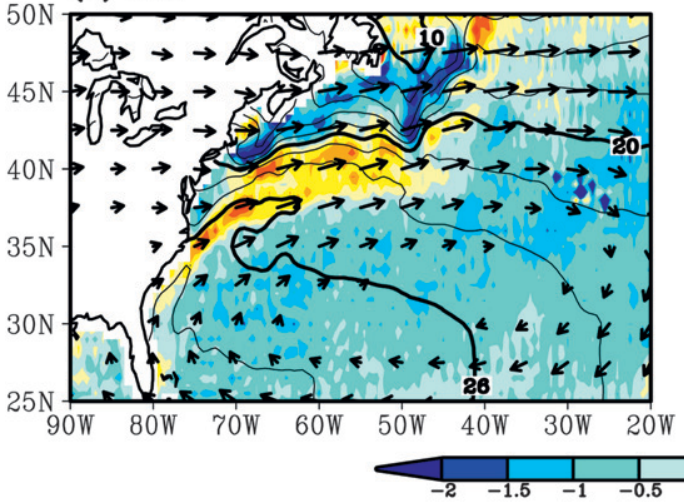

(b) MAM

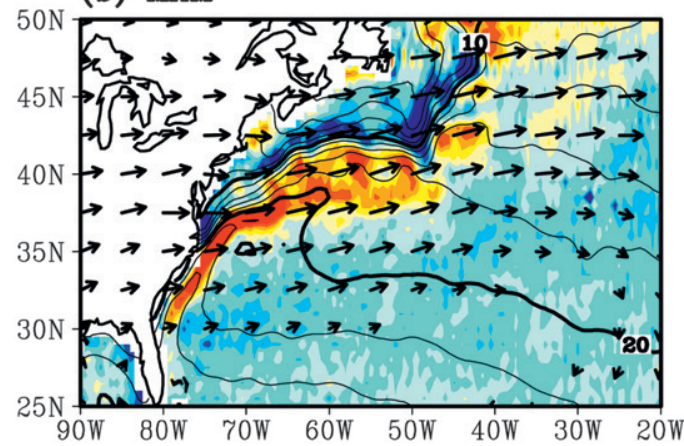

(d) SON

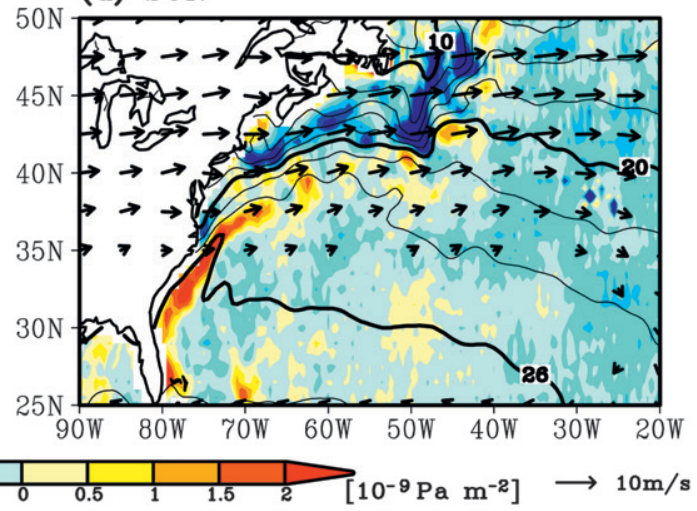

FIG. 3. SLP Laplacian (color) and wind velocities at $850 \mathrm{hPa}$ (vectors) of ECMWF data along with SSTs (contour). Contour interval of SSTs are $2^{\circ} \mathrm{C}$, with thick contours of $10^{\circ}, 20^{\circ}$, and $26^{\circ} \mathrm{C}$.

estimated from a geoid model, hydrograph data, and buoys (Rio and Hernandez 2004).

\section{c. Gridded in situ observations}

Following Tokinaga et al. (2009), we use the International Comprehensive Ocean-Atmosphere Data Set (ICOADS), release 2.4, that contains surface meteorological measurements and weather information from ships (merchant, navy, and research), moored and drifting buoys, coastal stations, and other marine platforms. Because commonly used gridded ICOADS products show some unrealistic features (Minobe and Maeda 2005), we performed the following quality control. First, suspicious data are excluded from the International Maritime Meteorological Archive (IMMA) format of ICOADS using the subjective quality control of Minobe and Maeda (2005). Second, we remove data that depart from the climatological monthly mean by more than 2.5 standard deviations at each $1^{\circ} \times 1^{\circ}$ grid box and month, and construct a monthly dataset on a $1^{\circ} \times 1^{\circ}$ grid. A weighted average is applied using values at the grid point and eight surrounding points. We construct the monthly mean climatology of SLP from 1950 to 2006.

\section{Oceanic condition}

This section describes briefly surface oceanic conditions and their seasonal changes. Figure 1 shows the seasonally averaged geostrophic current velocities and SSTs. The seasonal mean current velocities are calculated as $\sqrt{\bar{u}^{2}+\bar{v}^{2}}$, where $\bar{u}$ and $\bar{v}$ are climatological seasonal means of surface geostrophic current velocities in the eastward and northward directions, respectively.

This paper adopts the terminology in Tomczak and Godfrey (2003) for the Gulf Stream system. The Gulf Stream that flows along the North American coast before reaching Cape Hatteras is called the Florida Current. At Cape Hatteras, the Gulf Stream separates from the coast and flows to the Grand Banks. The Gulf Stream between Cape Hatteras and the Grand Banks is referred to as the Gulf Stream proper. Around the Grand Banks, a portion of the Gulf Stream turns northward as the North Atlantic Current. Surface geostrophic velocity does not exhibit strong seasonality (Fig. 1), consistent with previous findings that the seasonal cycle of the Gulf Stream is weak both in meridional position (Taylor and Stephens 1998; Frankignoul et al. 2001) and near-surface velocity (Rossby and Gottlieb 1998). 
(a) DJF ICOADS

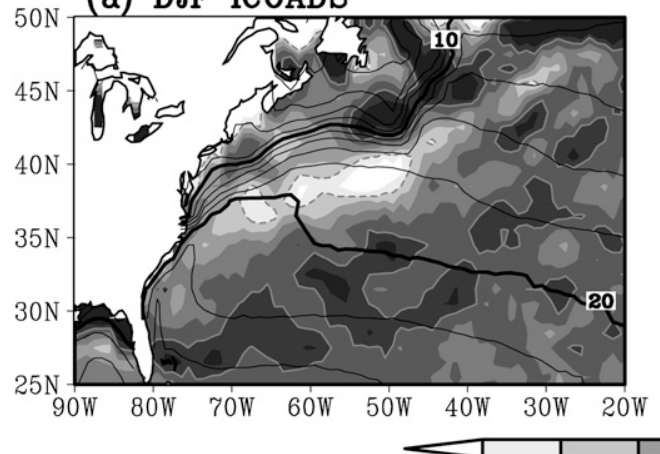

(d) MAM
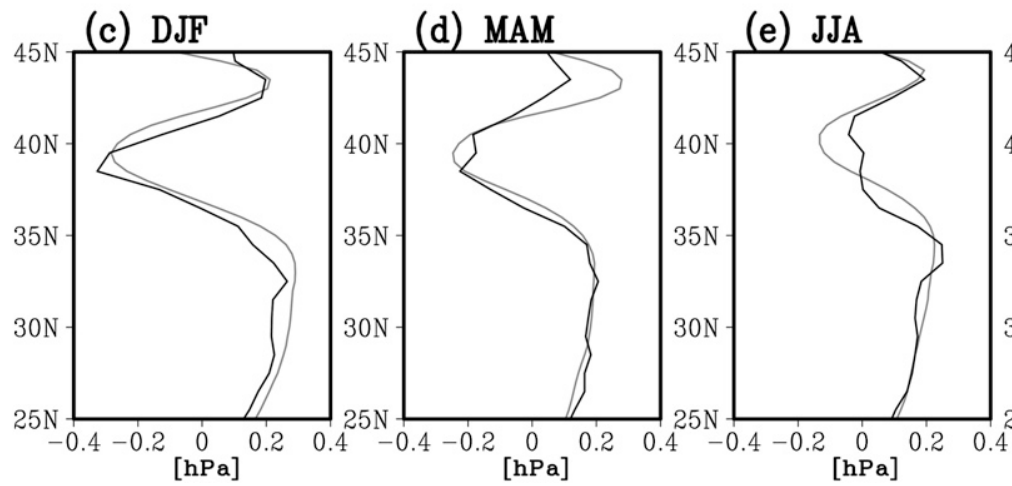

(b) DJF ECMWF

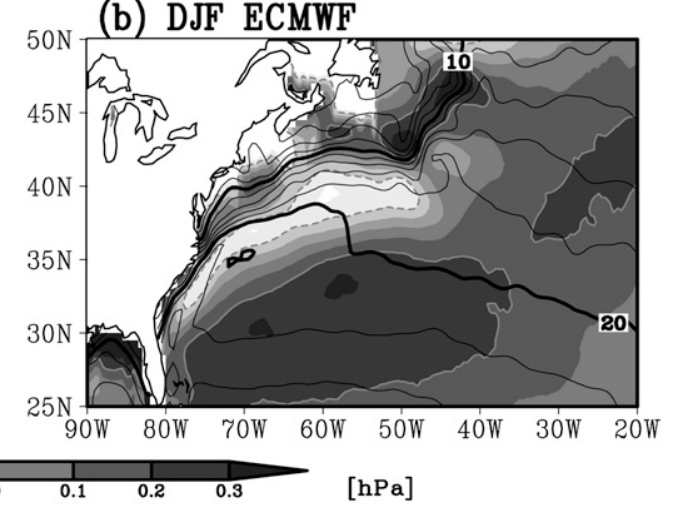

(f) SON

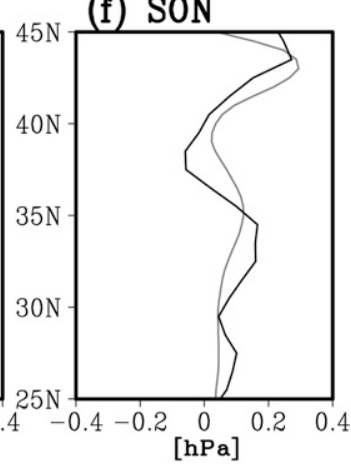

FIG. 4. (a) Meridionally high-pass filtered ICOADS climatology of SLP (shades and gray contours for $\pm 0.2 \mathrm{hPa}$ ) superimposed ICOADS SSTs in the winter season for the period from January 1950 to December 2006. Contour interval for SSTs is $2^{\circ} \mathrm{C}$, and thick contours are drawn for $10^{\circ}$ and $20^{\circ} \mathrm{C}$. (b) As in (a) but for ECMWF SLP superimposed ECMWF SSTs for the period from January 2002 to February 2006. (c) -(f) Meridionally high-pass filtered ICOADS (black line) and ECMWF (gray line) SLP averaged between $60^{\circ}$ and $50^{\circ} \mathrm{W}$ in each season.

The relationship between SST structure and the Gulf Stream current axis varies spatially. The Florida Current and the western Gulf Stream proper have a prominent warm core, that is, a local SST maximum along the Gulf Stream. The Gulf Stream proper is accompanied by a strong SST front on the shoreward side of the current axis. A sharp SST front accompanies the North Atlantic Current, collocated with the current axis.

SST exhibits strong seasonality-warm in summer and autumn and cold in winter and spring - typical of the midlatitudes. It is noteworthy that in summer SSTs over the Florida Current and the western Gulf Stream proper are as high as $26^{\circ}-29^{\circ} \mathrm{C}$, corresponding to the northern edge of Atlantic warm pool (e.g., Wang et al. 2006, 2007). As will become clear, high summer SSTs in this region are important for ocean-to-atmosphere influences. In addition to the overall seasonal warming and cooling, SST gradients across the Gulf Stream front exhibit prominent seasonal changes-strong in winter, weak in summer. Severe cold air outbreaks from the North American continent in winter substantially cool the slope water, resulting in a large SST contrast across the Gulf Stream.

\section{Surface wind convergence and precipitation}

Figure 2 shows the seasonal mean convergence of equivalent neutral wind velocity at $10 \mathrm{~m}$, estimated from QuikSCAT observations. Wind convergence is pronounced on the offshore side of the SST front, roughly collocated with the current axes of the Florida Current and Gulf Steam proper. On the other hand, wind divergence prevails over the slope waters and over the SST front of the North Atlantic Current. The convergence distribution is consistent with that in the annual mean analysis of Minobe et al. (2008), but exhibits a stronger magnitude in winter than in summer. Similar spatial and seasonal variations of surface wind divergence are also found in the ECMWF operational analysis.

A good correspondence between wind convergence and SLP Laplacian is found in all seasons (Fig. 3). Minobe et al. (2008) interpreted this relationship with the pressure adjustment mechanism of Lindzen and Nigam (1987). The SST modifies boundary layer air temperature, and the resultant pressure anomalies produce wind convergence (divergence) over relatively warm (cold) 
(a) DJF

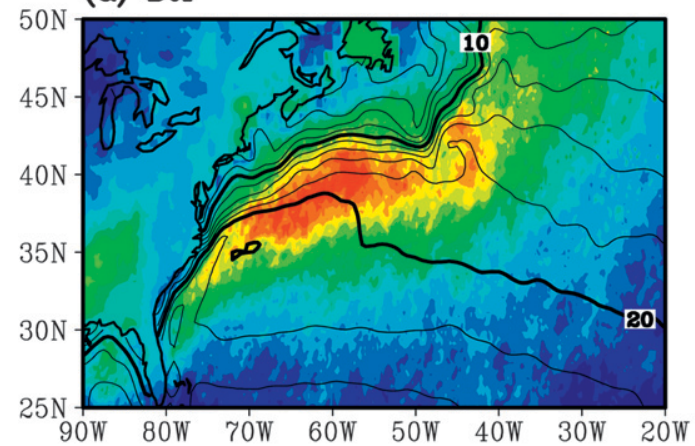

(c) JJA

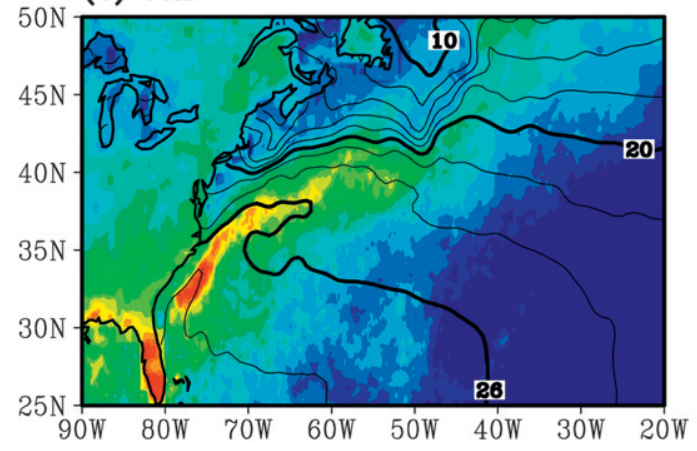

(b) MAM

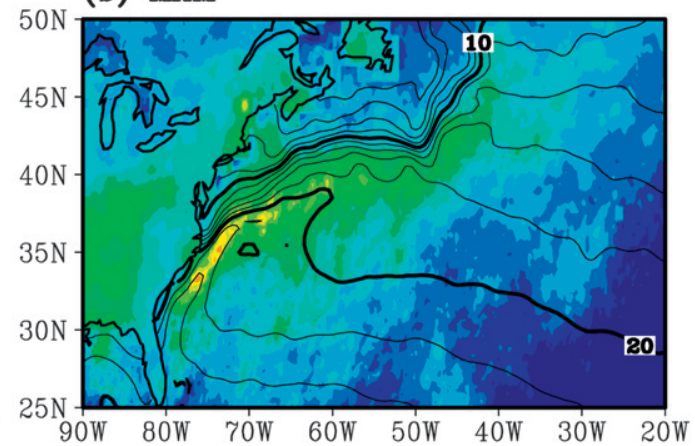

(d) SON

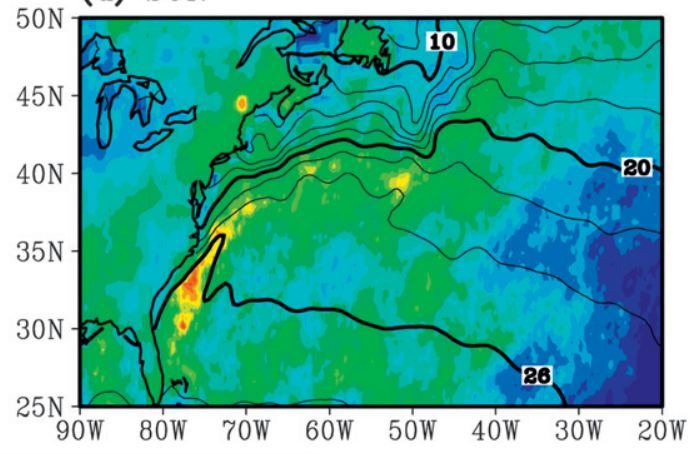

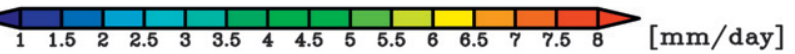

FIG. 5. Satellite-derived seasonal mean precipitation rate ( $\left.\mathrm{mm} \mathrm{day}^{-1}\right)$ (color) and SSTs (contours).

SSTs. With the modified formulation of Neelin (1989), it can be shown that wind convergence is proportional to the Laplacian of SLP (Minobe et al. 2008). Previous numerical studies indicate the importance of pressure adjustments over the Gulf Stream on weather time scales (Warner et al. 1990; Doyle and Warner 1993; Song et al. 2006). Also, studying the mean atmospheric response to an idealized SST front, Feliks et al. (2004) reported the importance of the Laplacian of air temperature in the MABL, which is closely related to the Laplacian of SLP. It is interesting to note that the SLP Laplacian captures not only the overall patterns of wind convergence but also some small-scale features associated with SST frontal meanders from $60^{\circ}$ to $50^{\circ} \mathrm{W}$ in winter and springin particular, the local maximum of wind divergences around $42^{\circ} \mathrm{N}, 48^{\circ} \mathrm{W}$ (Fig. 3). We note that the Gulf Stream effects cannot be easily seen in the raw SLP fields, masked by large-scale gradients associated with the midlatitude westerlies.

The pressure adjustment may not be the only mechanism for wind divergence variations across the Gulf Stream system. A popular explanation for the in-phase relation between SST and wind (e.g., Xie et al. 2002; Chelton et al. 2004; O'Neill et al. 2003, 2005) is the vertical mixing mechanism (Wallace et al. 1989), in which the near-surface atmosphere destabilizes over warmer SSTs and the intensified vertical mixing brings high momentum from aloft to accelerate surface wind. Alternatively, Samelson et al. (2006) recently argued that the in-phase relation between SST and wind speed is not actually due to the enhanced vertical mixing of the momentum, but is caused by the deepening of the MABL: they called this mechanism a boundary layer depth coupling mechanism. As illustrated by Chelton et al. (2004), the vertical mixing mechanism (or boundary layer depth coupling mechanism) causes wind divergence when the wind blows from cold to warm water across a SST front. With the prevailing westerlies, the vertical mixing mechanism may contribute wind divergence over the western Gulf Stream proper and the North Atlantic Current (Fig. 3). Indeed, Chelton et al. (2004) reported a good correspondence between the wind convergence and downwind SST gradients over a region $\left(35^{\circ}-55^{\circ} \mathrm{N}, 60^{\circ}-\right.$ $30^{\circ} \mathrm{W}$ ) that includes the SST front over the North Atlantic Current. Neither vertical mixing nor the boundary layer depth coupling mechanism, however, appears to explain the wind convergence over the Florida Current and the Gulf Stream proper. This is because, for wind 
(a) DJF

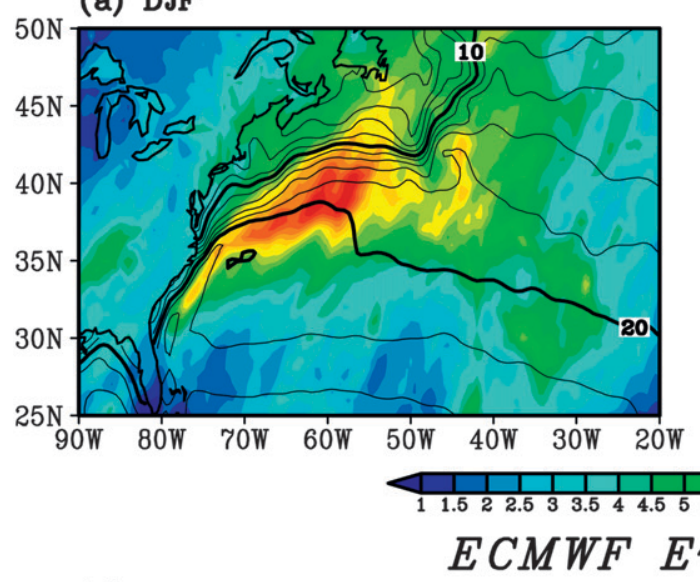

(c) DJF

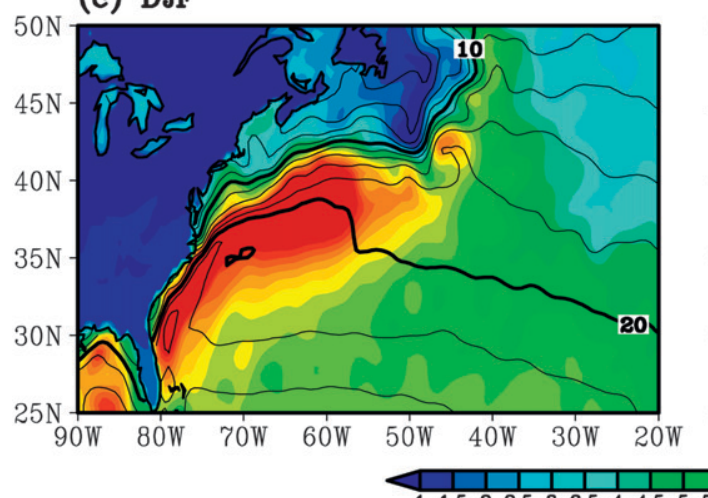

(b) JJA

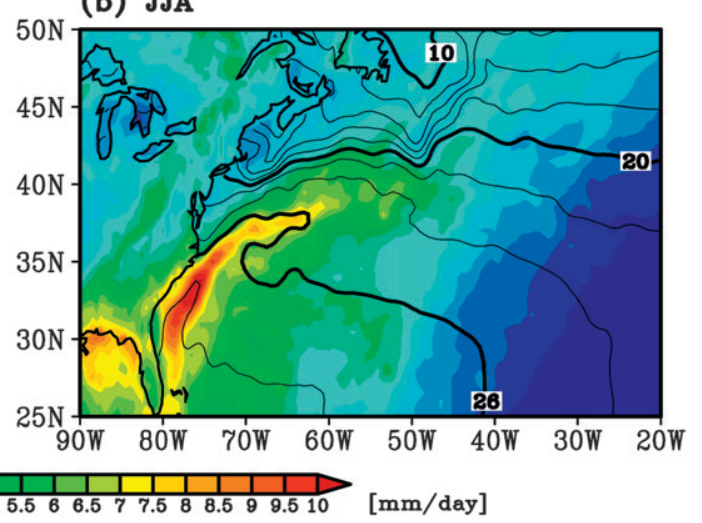

vaporation

(d) JJA

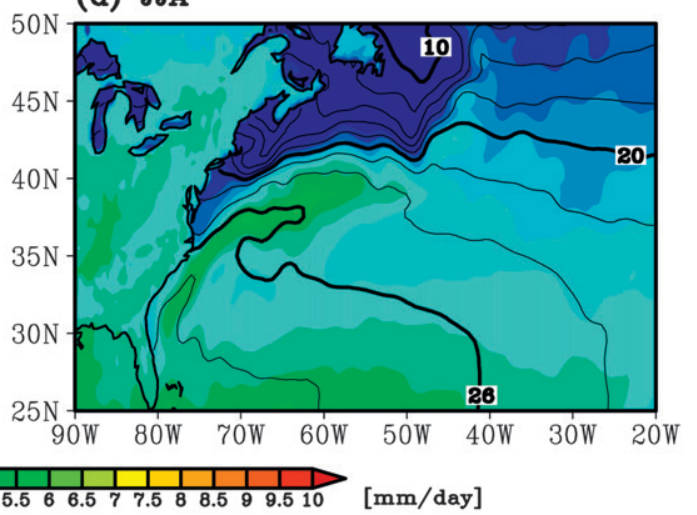

Evaporation - Precipitation

(e) DJF

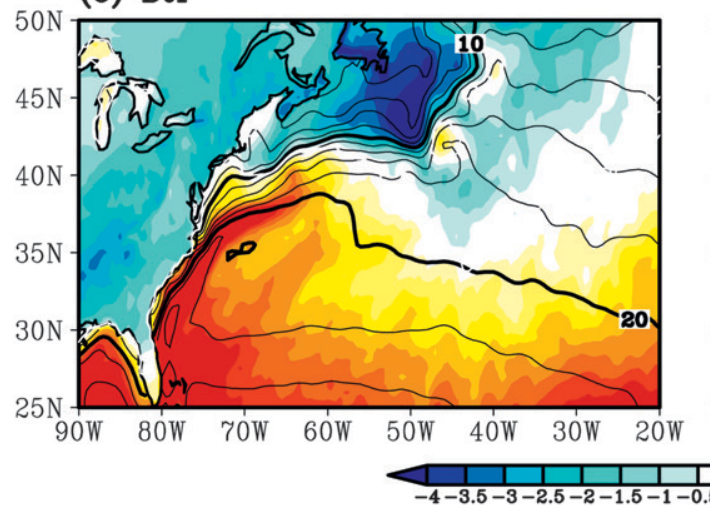

(f) JJA

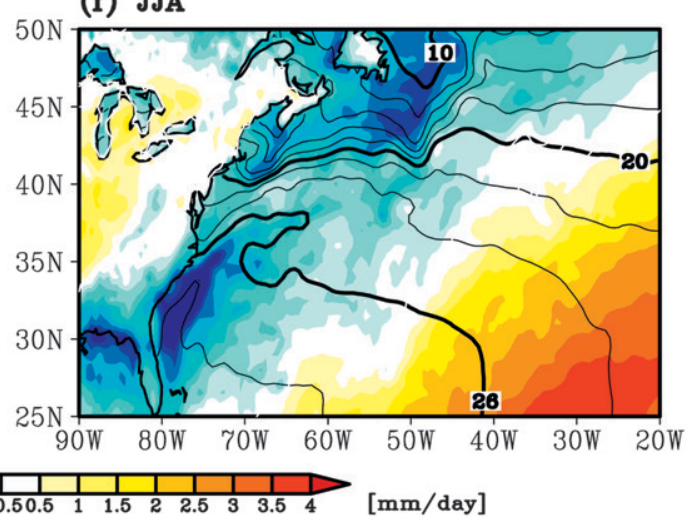

FIG. 6. (top) Rain rate, (middle) evaporation, and (bottom) their difference in (left) winter and (right) summer of ECMWF data. Superimposed are SSTs.

convergence by these mechanisms, the wind must blow from warm to cold water across the front, but it is not the case there (Figs. 2 and 3).

The Gulf Stream effect on SLP is confirmed by ICOADS observations. Figure 4 compares meridionally high-pass filtered SLPs between ICOADS and ECMWF in winter. The high-pass filtering is conducted by removing a $7^{\circ}$ running mean in the meridional direction from the original SLP. Negative high-pass filtered SLPs just over the Gulf Stream proper (south of the SST front) and positive SLPs over the North Atlantic Current are prominent in ICOADS (Fig. 4a), consistent with ECMWF (Fig. 4b). SLP signatures over the Florida Current are less evident in ICOADS than in ECMWF, possibly due to the end 
effect of spatial filtering close to the coast. The zonal average of high-pass filtered SLPs from $60^{\circ}$ to $50^{\circ} \mathrm{W}$ shows striking similarity in magnitude and meridional structure between ICOADS and ECMWF in winter and spring, with negative high-pass filtered SLPs around $40^{\circ} \mathrm{N}$ and positive values around $43^{\circ} \mathrm{N}$ (Figs. $4 \mathrm{c}$ and $4 \mathrm{~d}$ ). In summer and autumn, the amplitude of high-pass filtered SLP is reduced, but meridional variations in SLP remain similar between ICOADS and ECMWF (Figs. 4e and 4f). Thus, ICOADS observations support the SLP adjustment mechanism to the Gulf Stream front.

The Gulf Stream anchors a distinctive rainband (Minobe et al. 2008). The seasonality of the rainband is generally similar to that of wind convergence. The rainband is most pronounced in the winter season, with enhanced precipitation around the current axis of the Gulf Stream proper (Fig. 5a). An interesting difference in seasonality between precipitation and wind convergence is found over the Florida Current, where precipitation is strongest in summer (Fig. 5c) without a concurrent enhancement in wind convergence (Fig. 2). Rain rates in spring and autumn also show the Gulf Stream rainband but with weaker magnitudes (Figs. 5b and 5d). ECMWF data confirm the concurrent intensification of precipitation and wind convergence over the Gulf Stream proper in winter and the enhanced precipitation without strengthened surface wind convergence over the Florida Current in summer. Thus, precipitation displays two types of seasonal variations: one peaks in winter and the other in summer.

The relationship between precipitation and local evaporation shows interesting seasonal differences. Evaporation averaged over the study domain roughly equals precipitation. The ratio of evaporation to precipitation over the oceanic region in Fig. 6 is 105\%, 113\%, and 92\% for annual, winter, and summer averages, respectively. Thus, local evaporation supplies the bulk of water vapor for precipitation, as noted by Minobe et al. (2008) for the annual mean. In winter, evaporation is large over the Florida Current and the western Gulf Stream proper, roughly collocated with the Gulf Stream rainband (Figs. $6 \mathrm{a}$ and $6 \mathrm{c}$ ). To the east of $50^{\circ} \mathrm{W}$, precipitation is somewhat larger than local evaporation (Fig. 6e) and is partly contributed by moisture transported from the Florida Current region associated with the westerlies (Fig. 7a). In summer, the precipitation maximum over the Florida Current reaches $11 \mathrm{~mm}$ day $^{-1}$ (Fig. 6b), about twice the local evaporation (Figs. 6d and 6f). An analysis of JRA$25 / J C D A S$ indicates that additional water vapor for the Gulf Stream rainband comes from the south, riding on the southerlies east of Florida (Fig. 7b). The southerly winds have a surface core over $75^{\circ}-80^{\circ} \mathrm{W}$ at $30^{\circ} \mathrm{N}$, a feature sometimes called the southeast jet that is part of

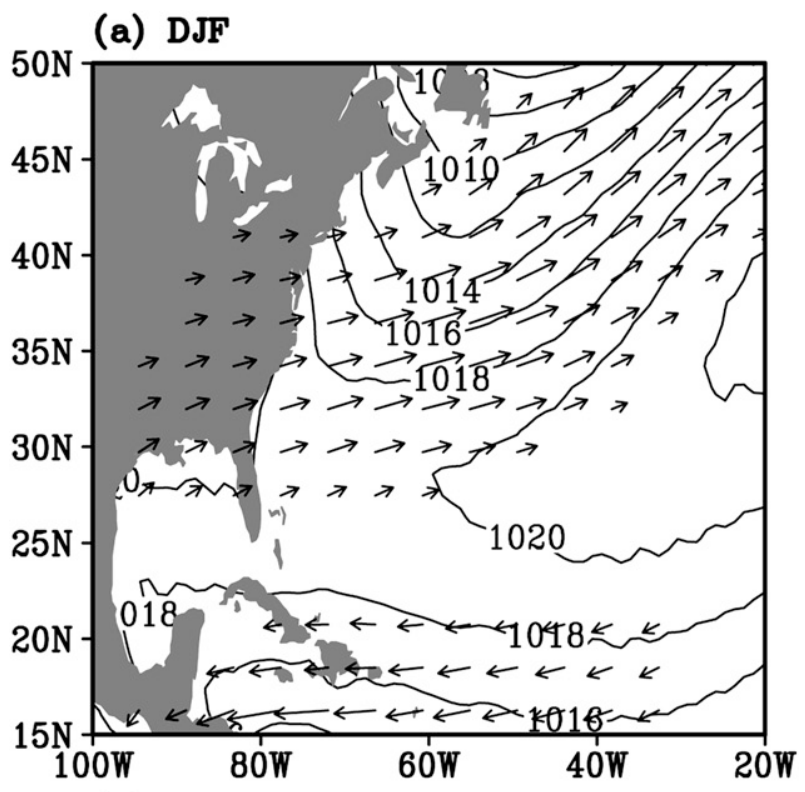

(b) JJA

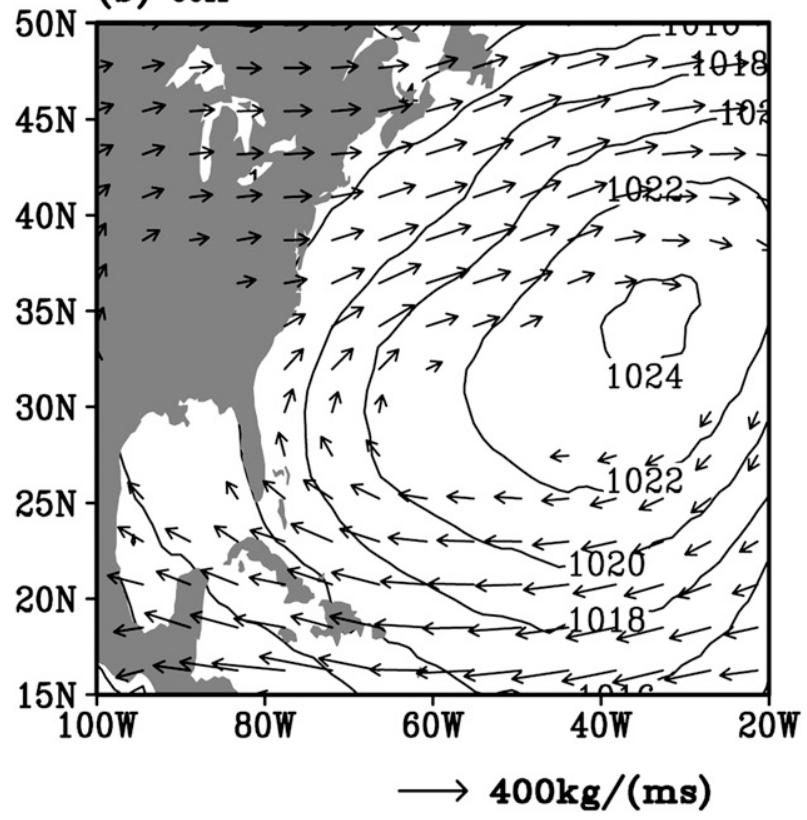

FIG. 7. (a) Winter and (b) summer vertically integrated moisture transport (vectors) and SLPs (contours) of JRA-25/JCDAS: moisture transport less than $100 \mathrm{~kg} \mathrm{~m}^{-1} \mathrm{~s}^{-1}$ not drawn.

the North Atlantic subtropical high (Wang et al. 2007). Thus, the summertime rainband over the Florida Current and the western Gulf Stream proper is associated with basinwide atmospheric circulation.

\section{Cloud and lightning}

The low-level (1100-680 hPa) cloud fraction estimated from AIRS/AMSU is generally large north of the 

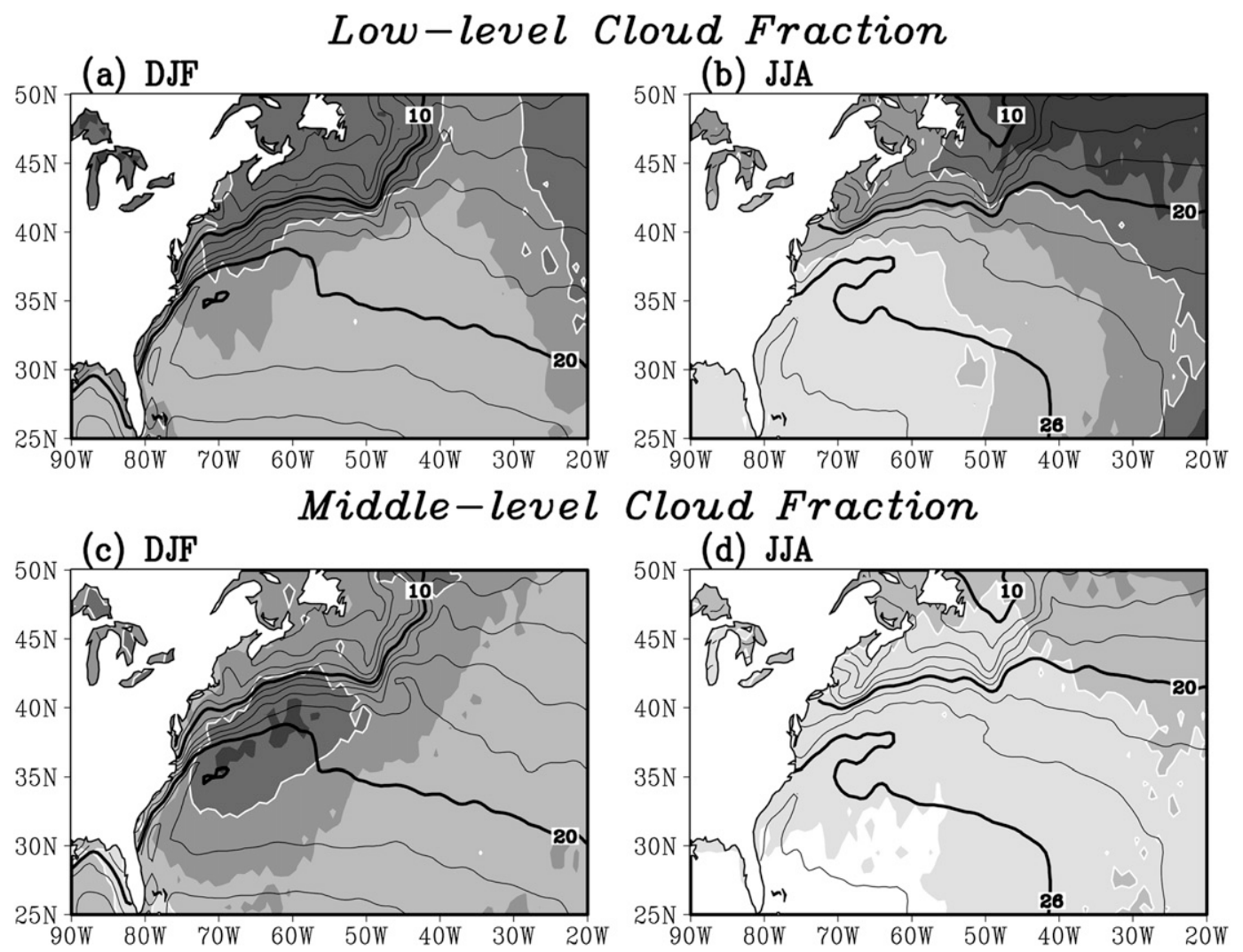

High-level Cloud Fraction

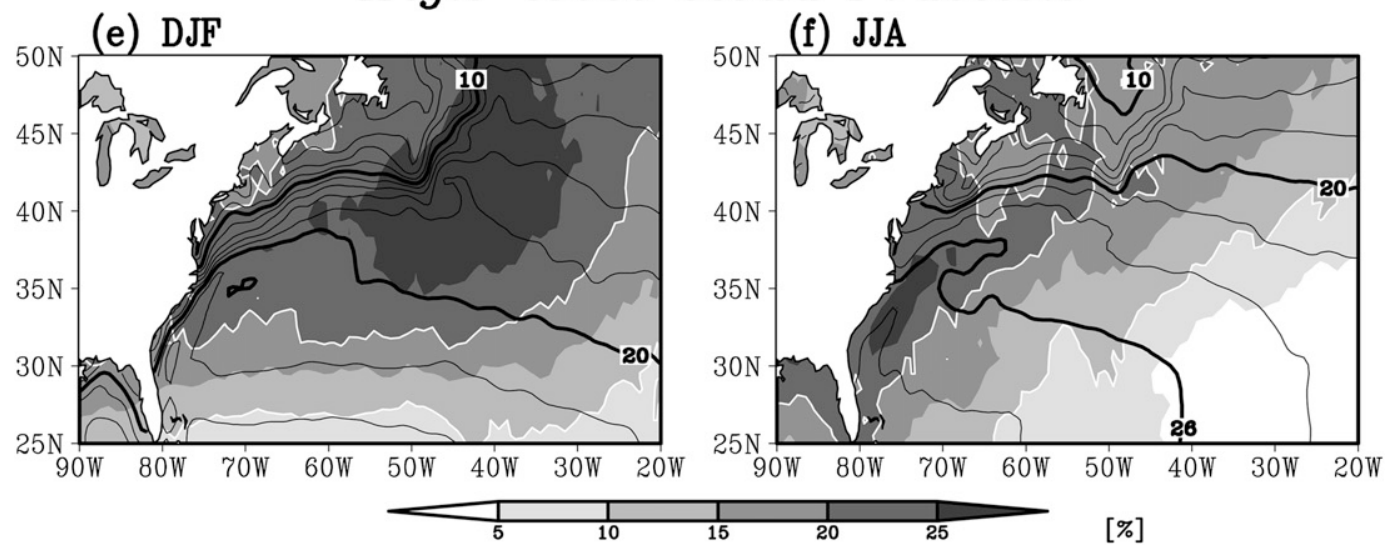

FIG. 8. (Top) Low, (middle) mid, and (bottom) high-level cloud fractions observed by AIRS/AMSU (shading and white contours at $10 \%$ and $20 \%$ ) in (left) winter and (right) summer. Superimposed is the ECMWF SSTs (black contours at $2^{\circ} \mathrm{C}$ interval with $10^{\circ}, 20^{\circ}$, and $26^{\circ} \mathrm{C}$ tick contours).

Gulf Stream and small south of it (Figs. 8a and 8b), consistent with widely known, frequent fog and haze formation over the slope waters (e.g., Sweet et al. 1981). Although the cloud fraction is large (small) in winter (summer), its meridional gradient across the Gulf Stream proper remains roughly unchanged year-round. The distribution of low-level clouds is very different from that of precipitation (Fig. 5) in both winter and summer seasons, as low-level clouds do not contribute much to precipitation.

The midlevel (680-440 hPa) cloud fraction shows interesting maxima over the Gulf Stream proper in the winter season (Fig. 8c). Weaker local maxima of the cloud fraction are also observed over the Gulf Stream proper in spring and autumn, but disappear in summer (Fig. 8d). This winter maximum of midlevel cloud fraction 


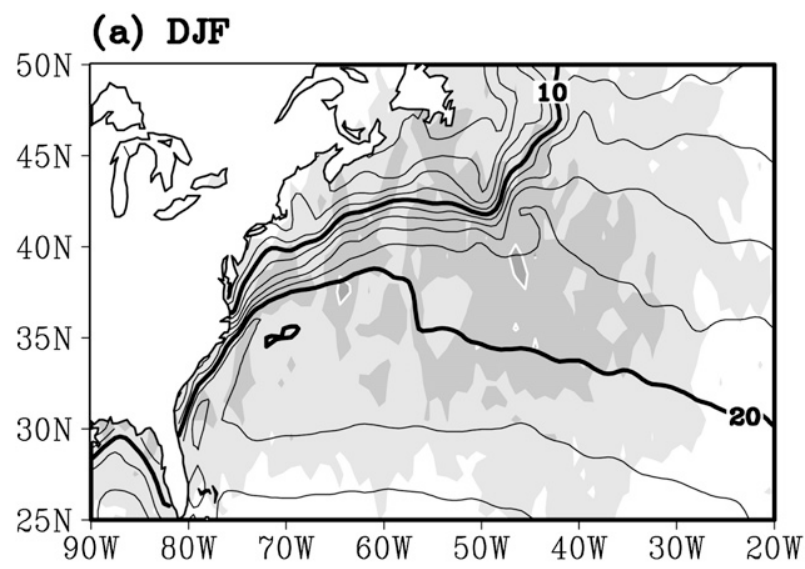

(b) JJA

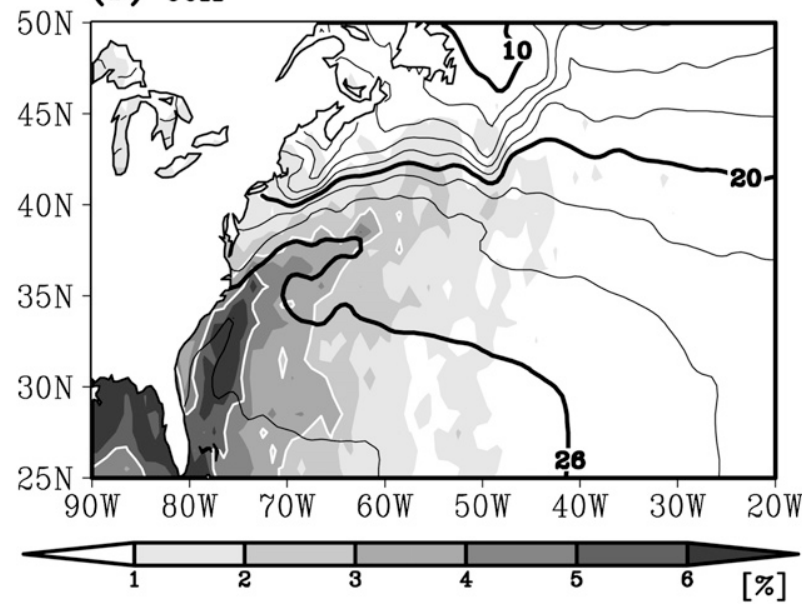

FIG. 9. (a) Winter and (b) summer cloud fraction at $200 \mathrm{hPa}$ observed AIRS/AMSU (shade and white contours at 3\% and 5\%). Superimposed is the ECMWF SSTs (black contours at $2^{\circ} \mathrm{C}$ interval with $10^{\circ}, 20^{\circ}$, and $26^{\circ} \mathrm{C}$ tick contours).

is associated with the seasonal strengthening of precipitation and surface wind convergence over the Gulf Stream proper, documented in the previous section.

The high-level (440-10 hPa) cloud fraction exhibits summertime maxima along the Florida Current and the Gulf Stream proper (Figs. 8e and 8f). In winter, the highcloud fraction is large over the eastern Gulf Stream proper and the North Atlantic Current with a broad pattern. The distribution difference of high-level cloud between the two seasons is confirmed by the frequency of high-level clouds represented by occurrence rate of low outgoing longwave radiation (OLR $<160 \mathrm{~W} \mathrm{~m}^{-2}$ ), whose annual mean pattern was shown by Minobe et al. (2008). At $200 \mathrm{hPa}$, cloud fraction is large in summer over the Florida Current, indicating deeper penetration of summertime clouds than in wintertime (Fig. 9). Lightning observations by the LIS/OTD support strong summertime convection over the Florida Current (Fig. 10). Notably,

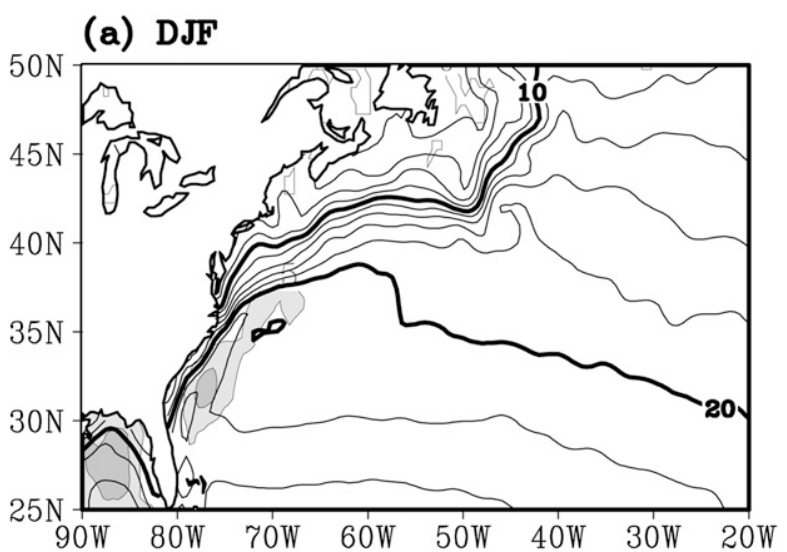

(b) JJA

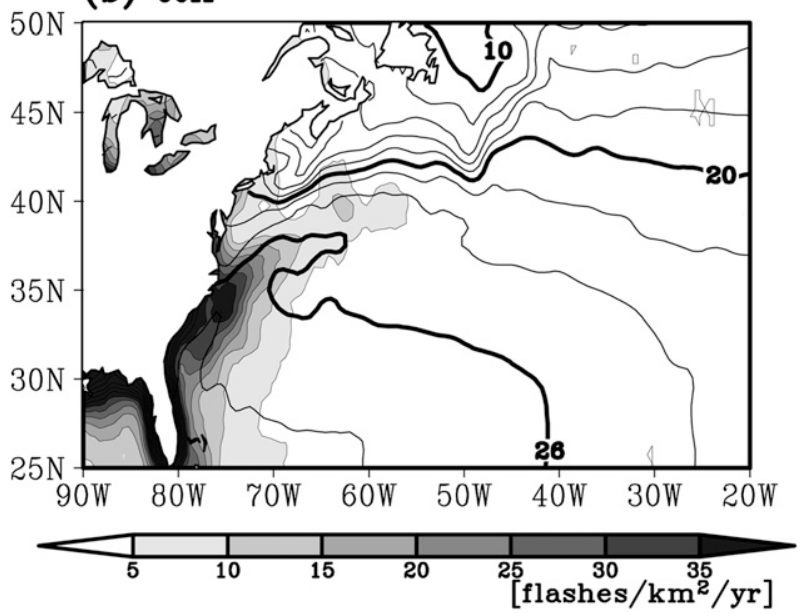

FIG. 10. (a) Winter and (b) summer lightning flash density (shade). Superimposed is the ECMWF SSTs (black contours at $2^{\circ} \mathrm{C}$ interval with $10^{\circ}, 20^{\circ}$, and $26^{\circ} \mathrm{C}$ tick contours).

summertime lightning flash rate displays a local maximum along the Florida Current and the western Gulf Stream proper, closely collocated with enhanced precipitation and high-level clouds. These results indicate that deep convection frequently occurs there in summer. Consistently in ECMWF forecasts, convective precipitation is active and accounts for three-quarters of the total precipitation over the Florida Current in summer.

\section{Vertical winds}

The vertical wind also exhibits seasonally dependent structures. In the lower troposphere $(850 \mathrm{hPa}$, Figs. 11a and 11b) the vertical wind shows a similar spatial and seasonal structure to that of the surface wind convergence in Fig. 2. Strong upward (downward) winds are found just over strong wind convergence (divergence).

In the middle troposphere $(500 \mathrm{hPa})$, prominent upward motion occurs in both winter and summer seasons 


\section{Upward Winds, $850 h P a$}
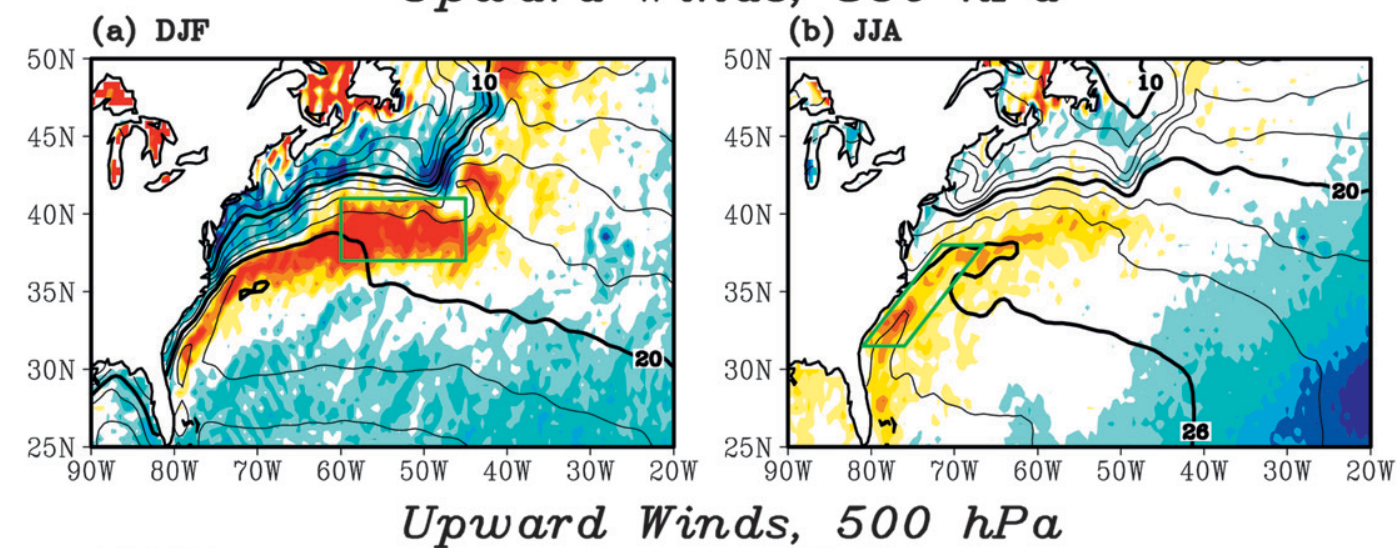

(c) DJF

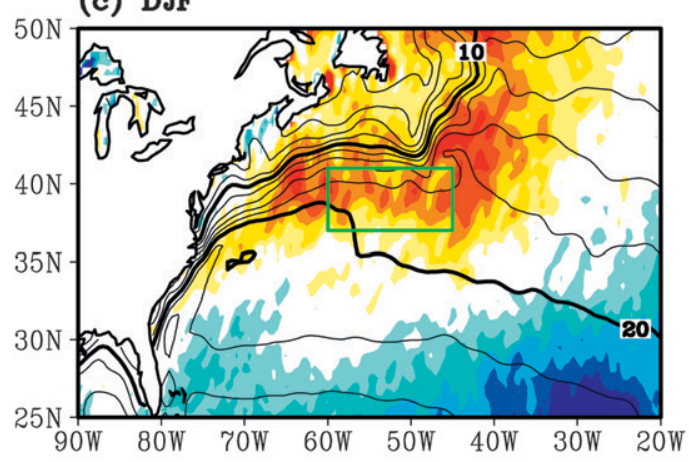

(d) JJA

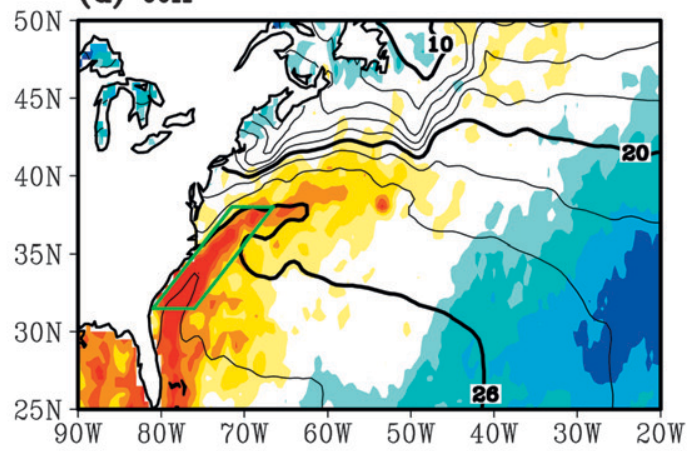

Upward Winds, $300 h P a$

(e) DJF

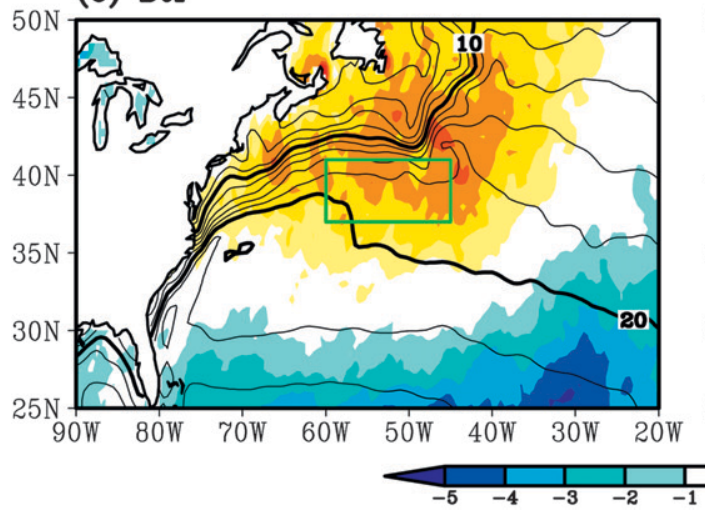

(f) JJA

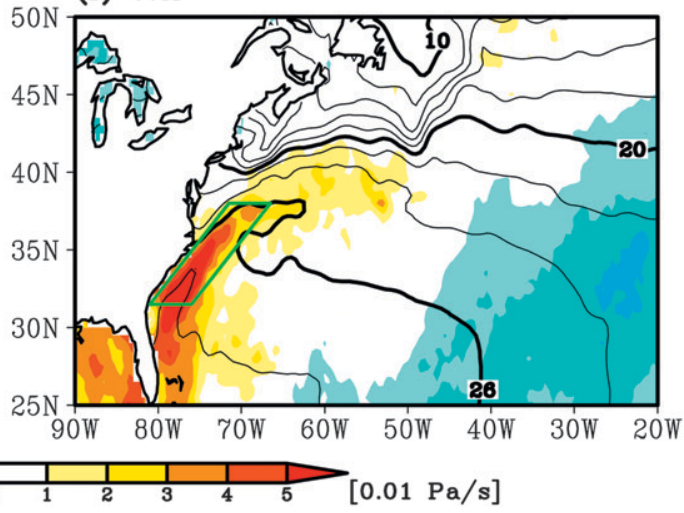

FIG. 11. Upward wind velocity $\left(10^{-2} \mathrm{~Pa} \mathrm{~s}^{-1}\right)$ at (top) 850 , (middle) 500, and (bottom) $300 \mathrm{hPa}$. Rectangles indicate the analysis regions in Figs. 12 and 14 for the (left) Gulf Stream proper and (right) Florida Current.

along the Gulf Stream but in different regions between the two seasons (Figs. 11c and 11d). In winter, the upward vertical wind follows Gulf Stream meandering, prominent over the Gulf Stream proper and on the east flank of the North Atlantic Current. In summer, on the other hand, upward winds are strong over the Florida Current and the western Gulf Stream proper. Upward winds at $500 \mathrm{hPa}$ are more closely associated with enhanced precipitation (Fig. 5) than the upward wind at
$850 \mathrm{hPa}$. Comparison with surface wind convergence (Fig. 2) indicates that upward winds at $500 \mathrm{hPa}$ occur over enhanced surface wind convergence in winter, but such a seasonal enhancement of surface convergence is not observed in summer.

The summer upward winds along the Florida Current and western Gulf Steam proper exhibit deep vertical penetration and are highly visible in the upper troposphere (300 hPa) (Fig. 11f). In winter, upward winds are 


\section{Gulf Stream Proper}

(a) ECMWF W

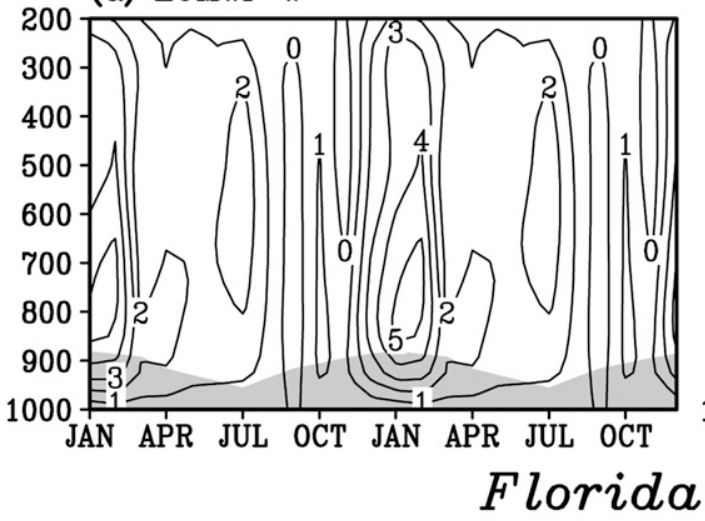

(c) ECMWF W

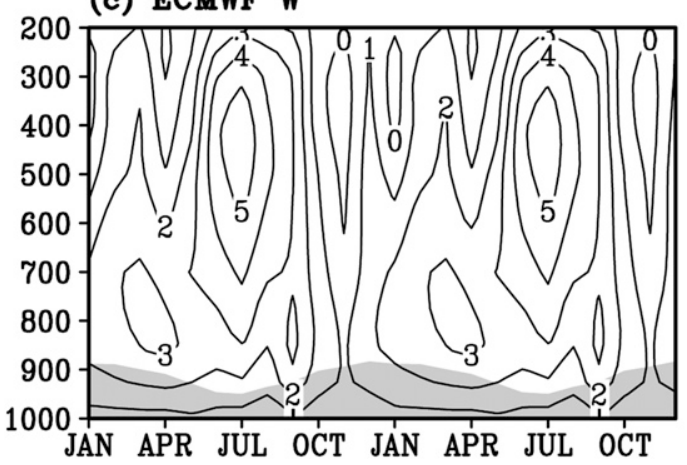

(b) ECMWF H-Conv.

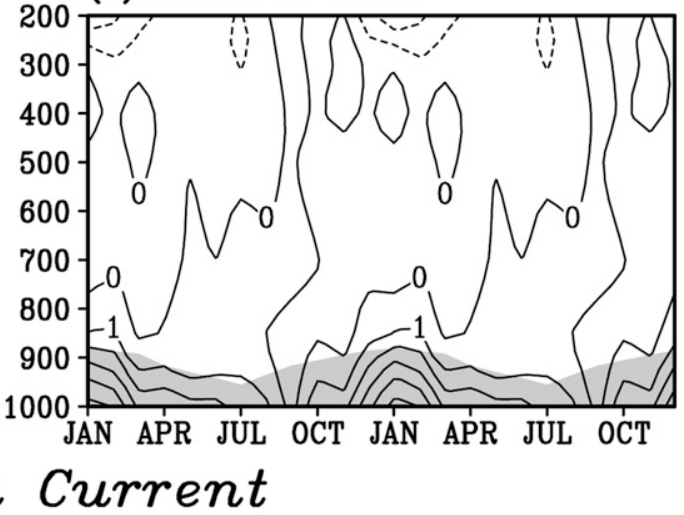

(d) ECMWF H-Conv.

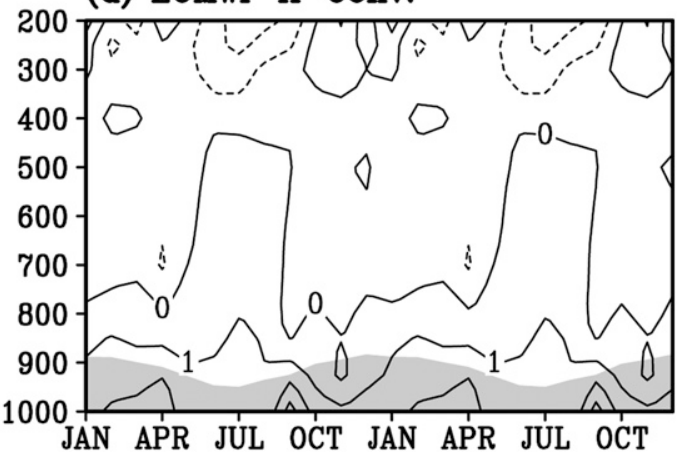

FIG. 12. (left) Monthly mean upward velocity and (right) horizontal convergence for the region shown in Fig. 11. Contour intervals are $1 \times 10^{-2} \mathrm{~Pa} \mathrm{~s}^{-1}$ for the upward velocities and $1 \times 10^{-6} \mathrm{~s}^{-1}$ for the horizontal convergence. Shading indicates the MABL.

still pronounced at $300 \mathrm{hPa}$ but have a broad spatial structure reminiscent of the high-level cloud distribution (Fig. 8e) and do not follow the Gulf Stream meandering (Fig. 11e). Consequently, upward motion in the upper troposphere is strongly constrained by the Gulf Stream in summer but not in winter.

Figure 12 shows vertical profiles of the vertical velocity in relation to horizontal wind convergence, averaged in two regions of prominent vertical motion. One region includes the central and eastern Gulf Stream proper (rectangle in Fig. 11a), hereafter referred to as the Gulf Stream proper. The other includes the Florida Current (parallelogram in Fig. 11b). Over the Gulf Stream proper, upward motion is strong in winter, located above lowlevel wind convergence (Figs. 12a and 12b). The wintertime upward wind velocity rapidly increases from 1000 to $850 \mathrm{hPa}$ and, consistently, horizontal wind convergence is almost confined in the MABL. Over the Florida Current, strong upward winds occur in summer, accompanied by horizontal wind convergences of a deep vertical structure (Figs. 12c and 12d). The upward motion increases continuously from 1000 to $500 \mathrm{hPa}$, accompanied by a deep layer of wind convergence slowly decreasing from the surface to the midtroposphere. Thus, the upward wind is directly related to horizontal convergence in the MABL over the Gulf Stream proper in winter, but horizontal convergence that feeds the upward wind also occurs above the MABL over the Florida Current in summer.

Another interesting difference in upward winds between winter and summer is found in their slanted structure. The wintertime ascent over the Gulf Stream proper tilts toward the north, as seen in the annual mean figure of Minobe et al. (2008) (Fig. 13a). The summertime upward winds show such a tilt neither over the Florida Current (Fig. 11) nor over the Gulf Stream Proper (Fig. 13b). Thus, the slanted structure is specific in winter.

\section{Atmospheric heating}

Results in the previous sections show that the wintertime and summertime responses to the Gulf Stream system are different in a number of aspects. It is interesting, 


\section{ECMWF W}

(a) DJF

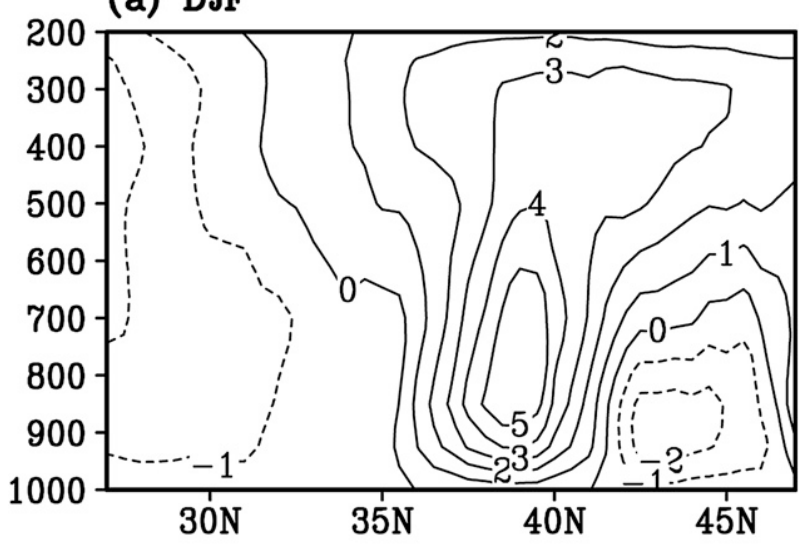

(b) JJA

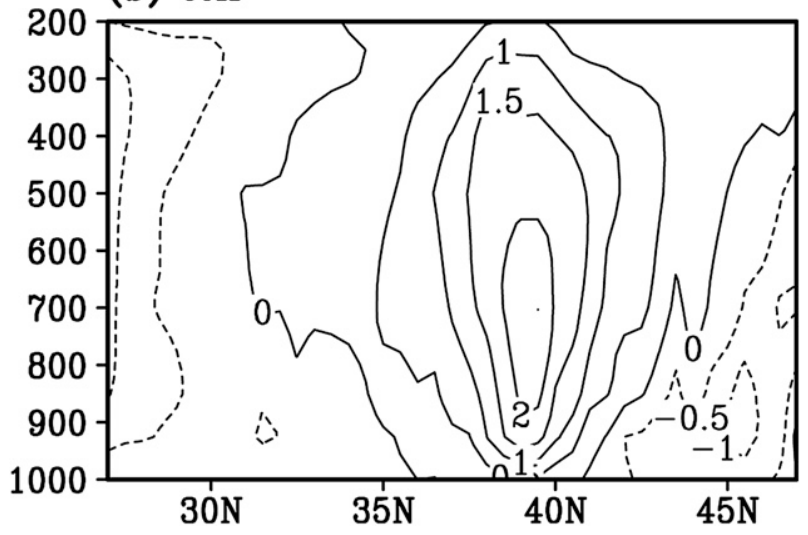

FIG. 13. Upward wind velocity averaged over the Gulf Stream proper $\left(60^{\circ}-45^{\circ} \mathrm{W}\right)$ in (a) winter and (b) summer. Contour interval is $1 \times 10^{-2} \mathrm{~Pa} \mathrm{~s}^{-1}$.

therefore, to examine atmospheric heating in these responses. JRA-25/JCDAS provides three-dimensional atmospheric heating in the following five components: advection, convective heating, large-scale condensation, vertical diffusion, and solar and longwave radiative heating rates. For simplicity, the sum of convective and large-scale condensation heating rates is referred to as latent heating. The vertical diffusion includes the sensible heat flux from the surface and is referred to as sensible heating. We now examine the seasonal variations of these heating rates over the Gulf Stream proper and the Florida Current. We focus on the latent and sensible heating rates, as they are much larger than the radiative heating rates.

Figure 14a shows that the diabatic heating rate has its maximum in the winter season over the Gulf Stream proper (rectangle in Fig. 11a). This reflects the fact that both sensible and latent heating reaches a maximum in winter, but with different vertical structures. Strong sensible heating is observed below $900 \mathrm{hPa}$, while latent heating, mainly due to convection, occurs above $900 \mathrm{hPa}$ and gradually decreases in magnitude above $800 \mathrm{hPa}$ (Fig. 14b). The combined latent and sensible heating in winter yields a major peak from the surface to $800 \mathrm{hPa}$ and a secondary peak in the midtroposphere.

The diabatic heating over the Florida Current (parallelogram in Fig. 11b) exhibits the shallow maximum in winter, as in the case over the Gulf Stream proper, but there is another peak in summer at $400-500 \mathrm{hPa}$ with a wider vertical structure (Fig. 14c). The winter shallow maximum is due to sensible heating (not shown), while the summer deep maximum is caused by convective heating, which displays a pronounced peak in the middle and upper troposphere (Fig. 14d). The summertime middletropospheric maximum of latent heating in this region is consistent with the aforementioned strong precipitation (Fig. 5), enhanced cloud fraction, and the deep upward motion in the upper troposphere (Figs. 9 and 11).

The shallow diabatic heating maximum found over the Gulf Stream proper in winter and the deep maximum over the Florida Current in summer are related to a bimodal behavior of the maximal heating heights (Fig. 15a). Heights of the maximal total diabatic heating at each grid and each month over the analysis region $\left(25^{\circ}-50^{\circ} \mathrm{N}, 90^{\circ}-20^{\circ} \mathrm{W}\right.$, land excluded $)$ exhibit two distinct maxima: one in the middle $(400-600 \mathrm{hPa})$ and one in the lower $(800-1000 \mathrm{hPa})$ troposphere. The shallow total diabatic heating and its components (Fig. 15b) are quite similar in vertical profile to those over the Gulf Stream proper in winter (Fig. 14b), while the deep heating and its components (Fig. 15c) are similar to those over the Florida Current in summer (Fig. 14d). Consequently, the bimodal behavior of atmospheric heating is closely related to different atmospheric responses to the Gulf Stream. Therefore, we refer to the atmospheric response characterized by shallow heating and strong wind convergence/divergence in the MABL as the shallow heating mode and that characterized by deep heating and strong upward winds in the middle troposphere as the deep heating mode. The shallow heating mode is mainly for the wintertime atmospheric response over the Gulf Stream proper, while the deep heating mode is for the summertime atmospheric response over the Florida Current.

\section{Conclusions and discussion}

We have examined seasonal variations of the atmospheric response to the Gulf Stream based on highresolution satellite data and ECMWF operational analysis and forecasts. The response may be classified into two modes with distinct spatiotemporal variations. 


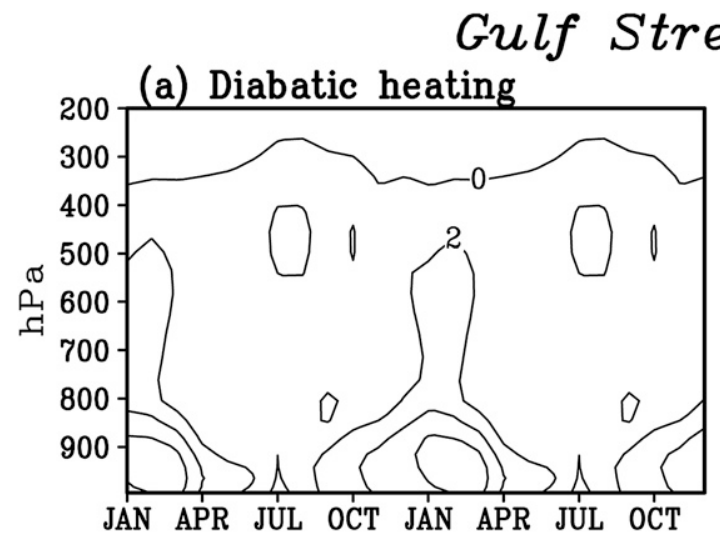

Proper

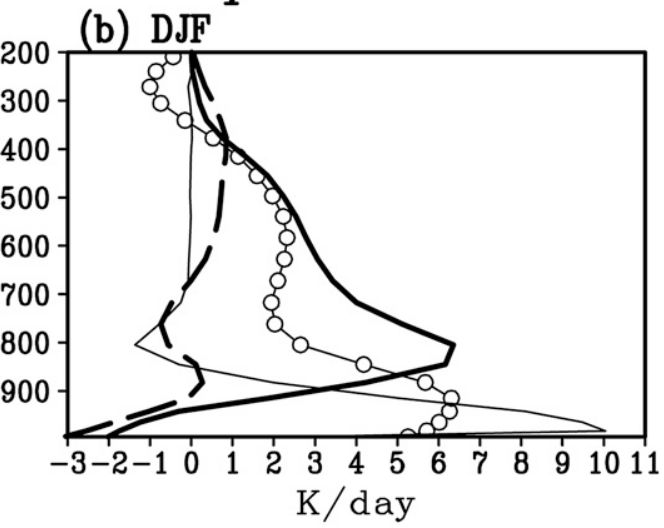

Florida Current
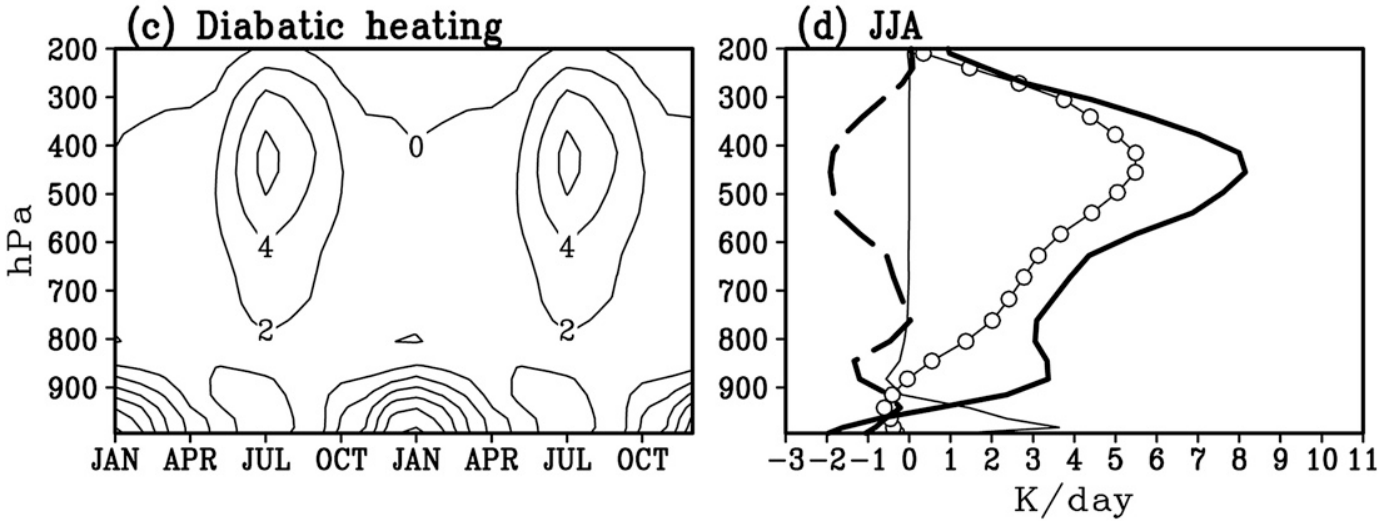

FIG. 14. (a),(c) Seasonal development of diabatic heating rate and (b) wintertime and (d) summertime vertical profiles of total diabatic heating rate (line with open circle), convective heating (thick solid line), large-scale condensation heating (thick dashed line), and sensible heating (thin solid line) over the (top) Gulf Stream proper and (bottom) Florida Current (the respective areas shown in Fig. 11). Contour interval for panels (a)(c) is $2 \mathrm{~K} \mathrm{day}^{-1}$.

The winter mode is best seen over the Gulf Stream proper, characterized by strong surface convergence highly correlated with the SLP Laplacian (Figs. 2 and 3), suggestive of the pressure adjustment mechanism. Pressure signatures are observed not only in the ECMWF operational analysis as Minobe et al. (2008) reported but also from in situ observations (Fig. 4). Precipitation is enhanced over surface convergence, accompanied by a high cloud fraction of midlevel clouds (Figs. 5 and 8). Local evaporation supplies much of the moisture for precipitation over the central and eastern Gulf Stream proper (Fig. 6). Wind convergence is confined in the MABL, and the shallow convergence is closely associated with upward motion in the troposphere (Fig. 12). Over the Gulf Stream proper, sensible and latent heating reaches an annual maximum in the winter season (Fig. 14). Sensible heating dominates the MABL, whereas the latent heating exhibits its peak at $\sim 800 \mathrm{hPa}$. The total heating is large from the surface to $850 \mathrm{hPa}$. For the convenience of discussion, this atmospheric response mode is referred to as the shallow heating mode. The shallow heating mode may occur in other major ocean fronts. Indeed, sharp changes are commonly reported in surface wind convergence-a key feature of the shallow heating mode-across SST fronts of the Kuroshio Extension (Nonaka and Xie 2003), the Agulhas Return Current (O'Neill et al. 2003, 2005), and the BrazilMalvinas Currents (Tokinaga et al. 2005).

The summer mode is most pronounced over the Florida Current and the western Gulf Stream proper, characterized by strong precipitation (Fig. 5), a large cloud fraction in the upper troposphere (Figs. 8 and 9), and enhanced lightning activity (Fig. 10). Suggestive of deep convection, upward motions penetrate into the upper troposphere but do not have prominent signatures of enhanced surface wind convergence (Figs. 2 and 11). Over the Florida Current, precipitation exceeds local evaporation, and the additional moisture is supplied by 


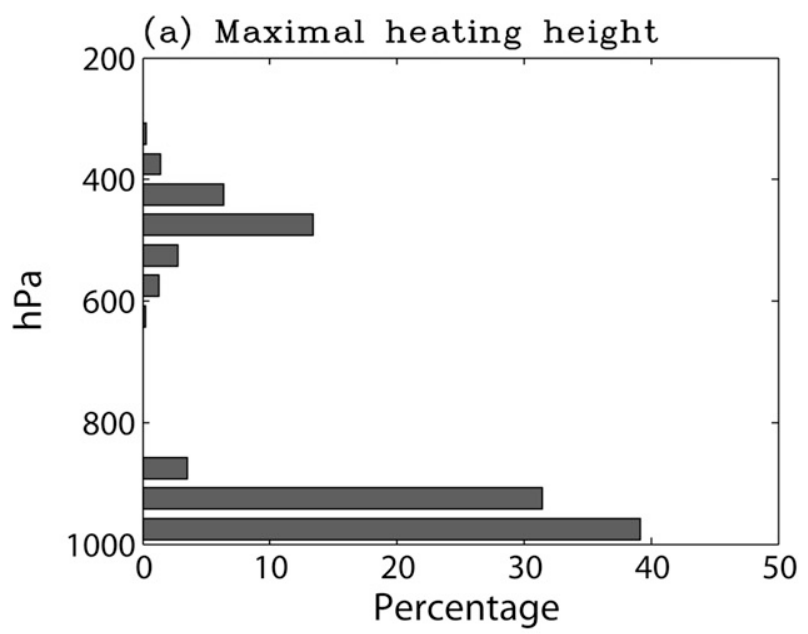

(b) Shallow heating
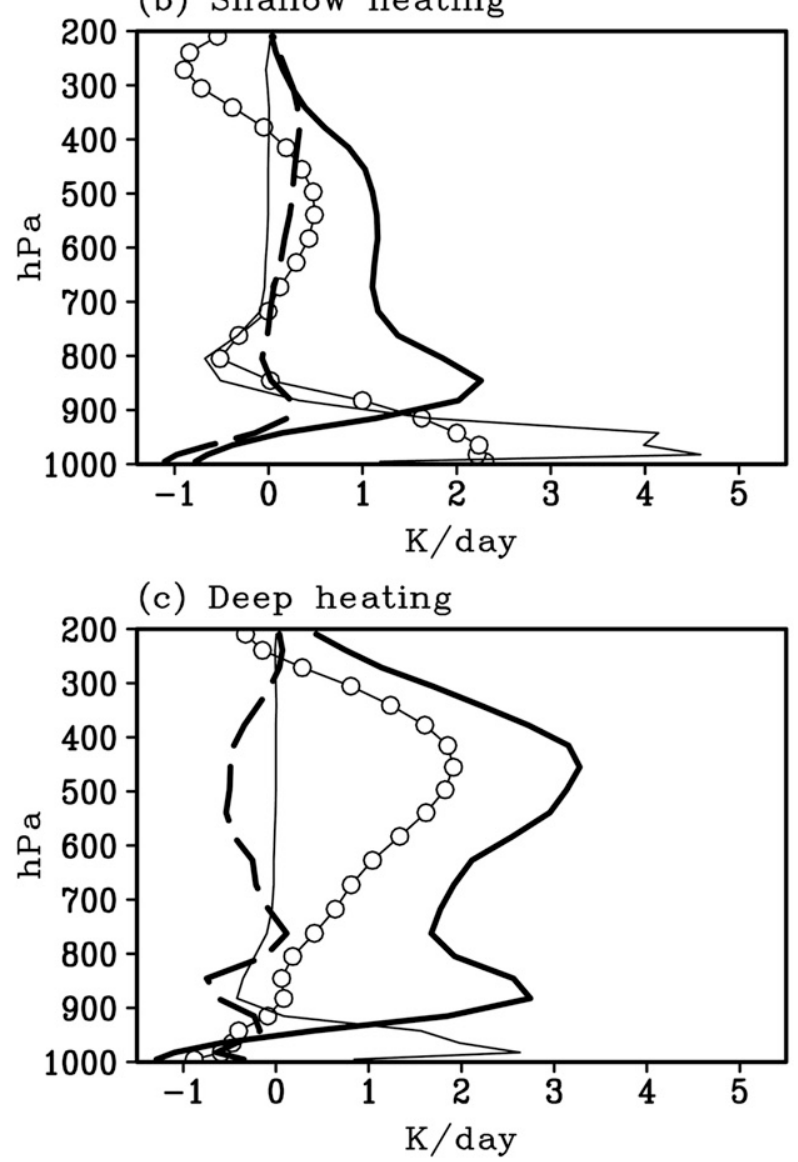

FIG. 15. (a) Histogram of heights of maximal total diabatic heating at each grid and each month over the analysis region $\left(25^{\circ}-\right.$ $50^{\circ} \mathrm{N}, 90^{\circ}-20^{\circ} \mathrm{W}$, land excluded) and averaged heating profiles for maximal height (b) lower than and (c) higher than $700 \mathrm{hPa}$. The line convention for (b),(c) is the same as for Figs. 14b,d: that is, total diabatic heating rate (line with open circle), convective heating (thick solid line), large-scale condensation heating (thick dashed line), and sensible heating (thin solid line). advection from the south as part of the basin-scale anticyclonic circulation over the North Atlantic (Fig. 7). Latent heating by convection dominates in summer with a maximum at $400-500 \mathrm{hPa}$ (Fig. 14). This atmospheric response mode may be referred to as the deep heating mode. Indeed, the height of maximal diabatic heating exhibits a prominent bimodal structure with one peak in the MABL and the other peak in the middle troposphere, corresponding to the shallow and deep heating modes, respectively (Fig. 15).

Boundary layer adjustments lead to locally enhanced evaporation and surface wind convergence on the warm flank of the Gulf Stream. In a companion paper using an atmospheric general circulation model, Kuwano-Yoshida et al. (2010) showed that the Gulf Stream's effect on precipitation is mainly convective and that local enhancement of evaporation and surface convergence makes the Gulf Stream a favorable place for long-lasting convection in both winter and summer. In one experiment that removes the Gulf Stream SST front, the local enhancement of convective precipitation disappears along the Gulf Stream, with much less effect on large-scale condensation. In their model, the atmosphere features a deep layer of conditional instability that enables deep convection in summer over the Gulf Stream, consistent with our observational results.

Our results suggest two necessary conditions for the deep heating mode. First, SST needs to exceed a certain threshold. In current climate, the SST threshold for deep convection is $\sim 26^{\circ}-27^{\circ} \mathrm{C}$ in the tropics, depending upon region and season (Graham and Barnett 1987; Waliser et al. 1993). A visual inspection of rain rate, high-level cloud, and vertical winds in the upper troposphere (Figs. 5, 9 , and 11) suggests that a summer mean SST of $24^{\circ}-26^{\circ} \mathrm{C}$ is necessary for the deep heating mode in the North Atlantic.

The second necessary condition for the deep heating mode is moisture transport from low-latitudes by the large-scale atmospheric circulation. For the precipitation maximum in the summertime rainband over the Florida Current, a substantial portion of the moisture is transported from the south on the west flank of the North Atlantic subtropical high (Fig. 7). The numerical study of Miyasaka and Nakamura (2005) showed that the subtropical high is primarily caused by a land-sea thermal contrast between maritime radiative cooling over the North Atlantic and continental sensible heating over North Africa. Consequently, the moisture transport from low latitudes is an external condition to ocean-toatmosphere influences of the Gulf Stream, and depends on the atmospheric circulation determined by largerscale processes.

These necessary conditions suggest that the deep heating mode may occur in the western part of other ocean 
ECMWF W

(a) DJF

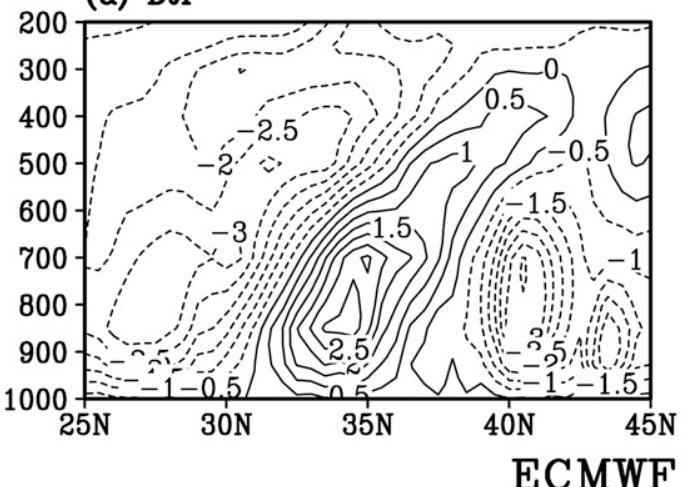

(c) DJF

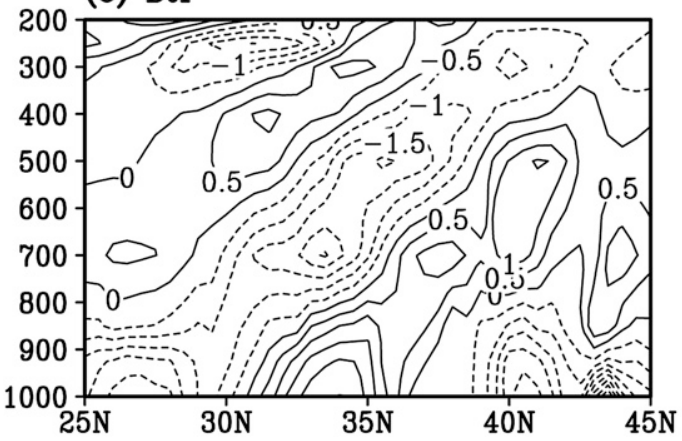

(b) JJ

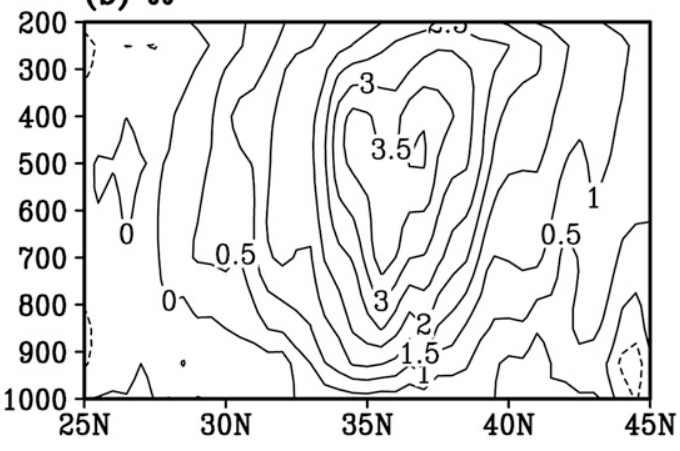

$\mathrm{H}-$ Conv.

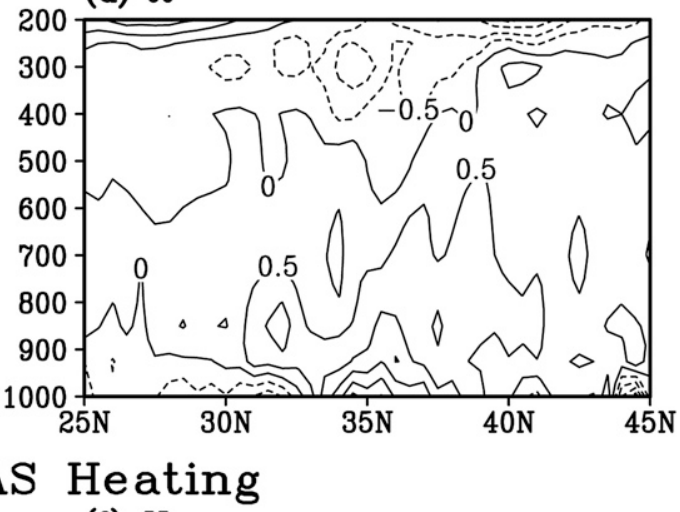

(f) JJ

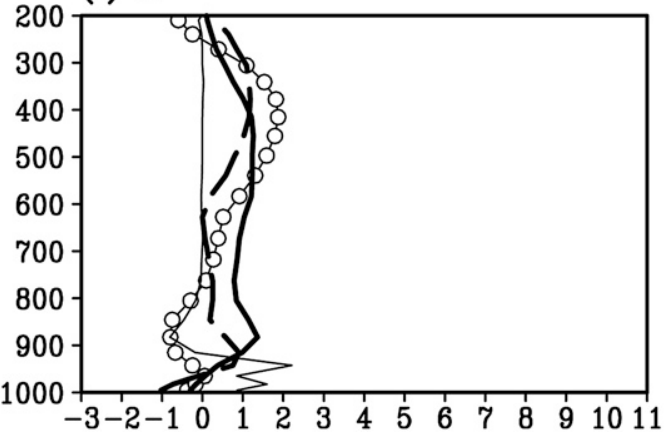

FIG. 16. (top) Upward wind velocity and (middle) horizontal wind convergence averaged between $145^{\circ}$ and $160^{\circ} \mathrm{E}$ and (bottom) heating rates averaged over $32^{\circ}-38^{\circ} \mathrm{N}, 145^{\circ}-160^{\circ} \mathrm{E}$ in (left) winter (December-February) and in (right) summer (June-July). Contour interval is (top) $0.5 \times 100 \mathrm{~Pa} \mathrm{~s}^{-1}$ and (middle) $0.5 \times 10^{-6} \mathrm{~s}^{-1}$. The heating rates for the bottom panels are total diabatic heating rate (line with open circle), convective heating (thick solid line), largescale condensation heating (thick dashed line), and sensible heating (thin solid line). The Kuroshio Extension is located at $\sim 35^{\circ} \mathrm{N}$.

basins in the summer season. The preference for the summer season is due to the high SST requirement. Western boundary currents transport heat poleward, helping to maintain high SSTs in the western basin. In addition, southerlies prevail in summer on the west flank of the subtropical anticyclone over the cool ocean, transporting moist air from low latitudes as in the North Atlantic. Over the Agulhas Return Current and
Brazil-Malvinas Currents, interesting oceanic signatures in surface wind were reported, but low SSTs (colder than $20^{\circ} \mathrm{C}$ even in local summer) probably prevent the deep heating mode from being dominant in the extratropical Southern Hemisphere.

The western North Pacific meets both conditions for the deep heating mode. Very recently, Tokinaga et al. (2009) showed deep penetration of upward winds in summer 
(June-July) over the Kuroshio Extension, accompanied by frequent cloud-top occurrence at $\sim 400 \mathrm{hPa}$. They also documented prominent surface wind convergence associated with SLP adjustments in the winter season (December-February). These results indicate that over the Kuroshio Extension, the shallow and deep heating modes are mainly at work in the winter and summer seasons, respectively. A pronounced rainband with frequent deep convection in summer, called "baiu" in Japan, extends eastward along the general direction of the Kuroshio Extension. The baiu rainband is anchored by the westerly wind jet in the midtroposphere, and SST gradients are hypothesized to help its extension east of Japan (Sampe and Xie 2010).

Our additional analysis indicates that upward motions over the Kuroshio Extension are accompanied by shallow and deep horizontal convergence in the winter and summer seasons, respectively (Figs. 16a-16d). In winter, sensible heating in the MABL and latent heating just above dominate, as in the shallow heating mode over the Gulf Stream proper (Figs. 16e and 14b). In summer, latent heating has a broad maximum at $\sim 400 \mathrm{hPa}$ and is larger than sensible heating (Fig. 16f), qualitatively similar to the deep heating mode along the Florida Current in Fig. 14d. The summertime latent heating over the Kuroshio Extension, however, is much weaker than that over the Florida Current, with comparable sensible heating in the boundary layer. Thus, over the summer Kuroshio Extension, the deep heating mode is at work but with larger contributions from the shallow heating mode than over the Florida Current. A relatively weak deep heating mode over the Kuroshio Extension may be due to low SSTs there $\left(22.5^{\circ} \mathrm{C}\right.$ over the region of Figs. 16) as compared to the Florida Current $\left(27.0^{\circ} \mathrm{C}\right.$ over the region of Fig. 14d). Another interesting difference in the atmospheric response between the Gulf Stream and the Kuroshio Extension is that the slanted structure of the wintertime upward wind over the Kuroshio Extension is much more prominent than that over the Gulf Stream. Such a tilt is clearly visible in the horizontal wind convergence over the Kuroshio Extension (Fig. 16c) but not so over the Gulf Stream (not shown).

Ascent is nearly collocated with the diabatic heating for both shallow and deep heating modes over the Gulf Stream, opposite to the argument of Hoskins and Karoly (1981) who suggested that diabatic heating is balanced by horizontal advection in the midlatitudes. In our analysis, vertical temperature advection dominates over horizontal advection for the deep heating mode (Fig. 17a). For the shallow heating mode, large diabatic heating from the surface to $800 \mathrm{hPa}$ is not balanced by temperature advection calculated from monthly-mean data, suggestive of an active role of weather disturbances (Fig. 17b). It is
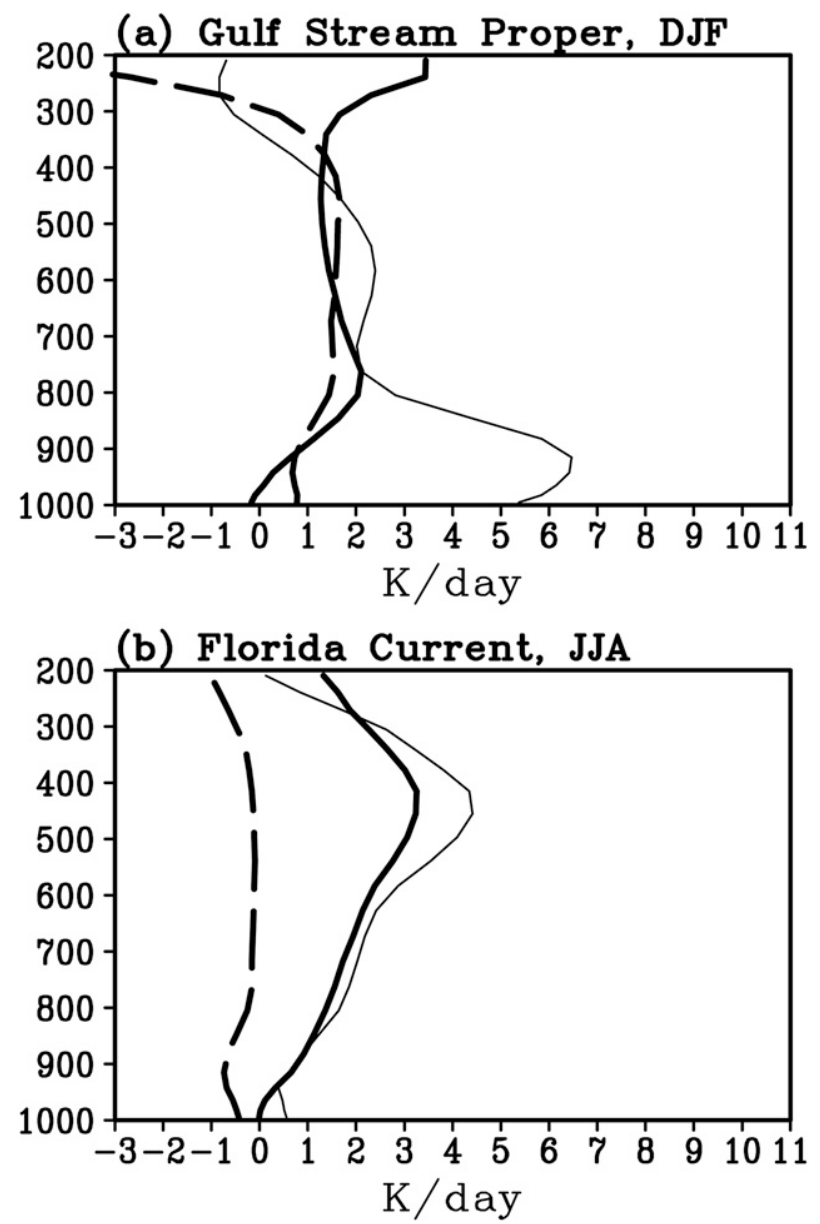

FIG. 17. Vertical profiles of vertical (thick solid line) and horizontal (thick dashed line) mean temperature advection and total temperature advection (thin line) (top) in winter over the Gulf Stream proper and (bottom) in summer over the Florida Current: areas as in Fig. 11. The mean vertical and horizontal advection is calculated from monthly mean climatologies of temperature and winds of JRA-25/JCDAS, but total temperature advection is provided as a part of the JRA-25/JCDAS dataset and includes advection due to submonthly components.

beyond our scope to investigate reasons for the discrepancy between the Hoskins and Karoly scale analysis and our observational result, but we note that their assumption of long waves is not satisfied for the atmospheric response to the Gulf Stream front and that the scale analysis does not consider the influence of synoptic disturbances. Over the Kuroshio Extension during summer, Sampe and Xie (2010) note a similar balance between convective heating and adiabatic cooling in ascending motion.

Further studies are necessary to understand how the deep and shallow heating modes are controlled by environmental conditions of the atmosphere and ocean. In particular, interactions between mean conditions studied 
in the present paper and shorter-term variations including synoptic variability (e.g., Alexander and Scott 1997; Zolina and Gulev 2003; Sampe and Xie 2007; Nakamura et al. 2008; Brayshaw et al. 2008) should be investigated. Also, since the Gulf Stream is part of the upper limb of the Atlantic meridional overturning circulation, which can give rise to a source of decadal predictability (Keenlyside et al. 2008), the shallow and deep heating modes may play some role in shaping predictable patterns of climate over the North Atlantic.

Acknowledgments. We thank M. Inatsu, M. Watanabe, K. Yamazaki, J. R. Small, L. O’Neill, and M. Ghil for discussions. Constructive comments from anonymous reviewers were quite helpful toward improving the presentation. The QuikSCAT data were obtained from RSS and the AIRS data from NASA GES DISC. This work was supported by Grant-in-Aid for Scientific Research defrayed by the Ministry of Education, Culture, Sports, Science and Technology of Japan; NASA; NOAA; NSF; and JAMSTEC.

\section{REFERENCES}

Alexander, M. A., and J. D. Scott, 1997: Surface flux variability over the North Pacific and North Atlantic. J. Climate, 10, 2963-2978.

Aumann, H. H., and Coauthors, 2003: AIRS/AMSU/HSB on the Aqua mission: Design, science objectives, data products, and processing systems. IEEE Trans. Geosci. Remote Sens., 41, 253-264.

Bjerknes, J., 1964: Atlantic air-sea interaction. Advances in Geophysics, Vol. 10, Academic Press, 1-82.

Bourras, D., G. Reverdin, H. Giordani, and G. Caniaux, 2004: Response of the atmospheric boundary layer to a mesoscale oceanic eddy in the northeast Atlantic. J. Geophys. Res., 109, D18114, doi:10.1029/2004JD004799.

Brayshaw, D. J., B. Hoskins, and M. Blackburn, 2008: The stormtrack response to idealized SST perturbations in an aquaplanet GCM. J. Atmos. Sci., 65, 2842-2860.

Cayan, D. R., 1992: Latent and sensible heat flux anomalies over the northern oceans: The connection to monthly atmospheric circulation. J. Climate, 5, 354-369.

Chelton, D. B., and M. H. Freilich, 2005: Scatterometer-based assessment of 10-m wind analyses from the operational ECMWF and NCEP numerical weather prediction models. Mon. Wea. Rev., 133, 409-429.

_ , and F. J. Wentz, 2005: Global microwave satellite observations of sea surface temperature for numerical weather prediction and climate research. Bull. Amer. Meteor. Soc., 86, 1097-1115.

— , M. G. Schlax, M. H. Freilich, and R. F. Milliff, 2004: Satellite measurements reveal persistent small-scale features in ocean winds. Science, 303, 978-983.

Christian, H. J., and Coauthors, 2003: Global frequency and distribution of lightning as observed from space by the Optical Transient Detector. J. Geophys. Res., 108, 4005, doi:10.1029/ 2002JD002347.
Ciasto, L. M., and D. W. J. Thompson, 2004: North Atlantic atmosphere-ocean interaction on intraseasonal time scales. J. Climate, 17, 1617-1621.

Czaja, A., and C. Frankignoul, 2002: Observed impact of Atlantic SST anomalies on the North Atlantic Oscillation. J. Climate, 15, 606-623.

Dong, S., S. L. Hautala, and K. A. Kelly, 2007: Interannual variations in upper-ocean heat content and heat transport convergence in the western North Atlantic. J. Phys. Oceanogr., 37, 2682-2697.

Doyle, J. D., and T. T. Warner, 1993: The impact of the sea surface temperature resolution on mesoscale coastal processes during GALE IOP 2. Mon. Wea. Rev., 121, 313-334.

Ducet, N., and P.-Y. Le Traon, 2001: A comparison of surface eddy kinetic energy and Reynolds stresses in the Gulf Stream and the Kuroshio current systems from merged TOPEX/Poseidon and ERS-1/2 altimetric data. J. Geophys. Res., 106 (C8), 16603 16622.

Feliks, Y., M. Ghil, and E. Simonnet, 2004: Low-frequency variability in the midlatitude atmosphere induced by an oceanic thermal front. J. Atmos. Sci., 61, 961-981.

Frankignoul, C., G. de Coetlogon, T. M. Joyce, and S. Dong, 2001: Gulf stream variability and ocean-atmosphere interactions. J. Phys. Oceanogr., 31, 3516-3529.

Graham, N. E., and T. P. Barnett, 1987: Sea surface temperature, surface wind divergence, and convection over tropical oceans. Science, 238, 657-659.

Hobbs, P. V., 1987: The Gulf Stream rainband. Geophys. Res. Lett., 14, 1142-1145.

Hoskins, B. J., and D. J. Karoly, 1981: The steady linear response of a spherical atmosphere to thermal and orographic forcing. J. Atmos. Sci., 38, 1179-1196.

Joyce, T. M., Y. O. Kwon, and L. Yu, 2009: On the relationship between synoptic wintertime atmospheric variability and path shifts in the Gulf Stream and the Kuroshio Extension. J. Climate, 22, 3177-3192.

Keenlyside, N. S., M. Latif, J. Jungclaus, L. Kornblueh, and E. Roeckner, 2008: Advancing decadal-scale climate prediction in the North Atlantic sector. Nature, 453, 84-88.

Kobashi, F., S. P. Xie, N. Iwasaka, and T. T. Sakamoto, 2008: Deep atmospheric response to the North Pacific oceanic subtropical front in spring. J. Climate, 21, 5960-5975.

Kuo, Y. H., M. A. Shapiro, and E. G. Donall, 1991: The interaction between baroclinic and diabatic processes in a numerical simulation of a rapidly intensifying extratropical marine cyclone. Mon. Wea. Rev., 119, 368-384.

Kushnir, Y., W. A. Robinson, I. Bladé, N. M. J. Hall, S. Peng, and R. Sutton, 2002: Atmospheric GCM response to extratropical SST anomalies: Synthesis and evaluation. J. Climate, 15, 2233 2256.

Kuwano-Yoshida, A., S. Minobe, and S.-P. Xie, 2010: Precipitation response to the Gulf Stream in an atmospheric GCM. J. Climate, 23, 3676-3698.

Li, X., W. Zheng, W. G. Pichel, C.-Z. Zou, P. Clemente-Colón, and K. S. Friedman, 2004: A cloud line over the Gulf Stream. Geophys. Res. Lett., 31, L14108, doi:10.1029/2004GL019892.

Lindzen, R. S., and S. Nigam, 1987: On the role of sea surface temperature gradients in forcing low-level winds and convergence in the tropics. J. Atmos. Sci., 44, 2418-2436.

Liu, W. T., and W. Tang, 1996: Equivalent neutral wind. JPL Publication 96-17, 8 pp.

X. Xie, P. S. Polito, S.-P. Xie, and H. Hashizume, 2000: Atmospheric manifestation of tropical instability wave observed 
by QuikSCAT and tropical rain measuring mission. Geophys. Res. Lett., 27, 2545-2548.

- — - and P. P. Niiler, 2007: Ocean-atmosphere interaction over Agulhas Extension meanders. J. Climate, 20, 5784-5797.

Minobe, S., and A. Maeda, 2005: A $1^{\circ}$ monthly gridded sea-surface temperature dataset compiled from ICOADS from 1850 to 2002 and Northern Hemisphere frontal variability. Int. J. Climatol., 25, 881-894.

—- A. Kuwano-Yoshida, N. Komori, S.-P. Xie, and R. J. Small, 2008: Influence of the Gulf Stream on the troposphere. Nature, 452, 206-209.

Miyasaka, T., and H. Nakamura, 2005: Structure and formation mechanisms of the Northern Hemisphere summertime subtropical highs. J. Climate, 18, 5046-5065.

Nakamura, H., T. Sampe, A. Goto, W. Ohfuchi, and S.-P. Xie, 2008: On the importance of midlatitude oceanic frontal zones for the mean state and dominant variability in the tropospheric circulation. Geophys. Res. Lett., 35, L15709, doi:10.1029/ 2008GL034010.

Namias, J., 1959: Recent seasonal interaction between North Pacific waters and the overlying atmospheric circulation. J. Geophys. Res., 64, 631-646.

- 1969: Seasonal interactions between the North Pacific Ocean and the atmosphere during the 1960s. Mon. Wea. Rev., 97, 173-192.

- 1 1972: Experiments in objectively predicting some atmospheric and oceanic variables for the winter of 1971-72. J. Appl. Meteor., 11, 1164-1174.

Neelin, J. D., 1989: On the interpretation of the Gill model. J. Atmos. Sci., 46, 2466-2468.

Nonaka, M., and S.-P. Xie, 2003: Covariations of sea surface temperature and wind over the Kuroshio and its extension: Evidence for ocean-to-atmosphere feedback. J. Climate, 16, 1404-1413.

O’Neill, L. W., D. B. Chelton, and S. K. Esbensen, 2003: Observations of SST-induced perturbations of the wind stress field over the Southern Ocean on seasonal timescales. J. Climate, 16, 2340-2354.

,,--- , and F. J. Wentz, 2005: High-resolution satellite measurements of the atmospheric boundary layer response to SST variations along the Agulhas Return Current. J. Climate, 18, 2706-2723.

Onogi, K., and Coauthors, 2007: The JRA-25 reanalysis. J. Meteor. Soc. Japan, 85, 369-432.

Park, K.-A., P. C. Cornillon, and D. L. Codiga, 2006: Modification of surface winds near ocean fronts: Effects of Gulf Stream rings on scatterometer (QuikSCAT, NSCAT) wind observations. J. Geophys. Res., 111, C03021, doi:10.1029/2005JC003016.

Peng, S., W. A. Robinson, and M. P. Hoerling, 1997: The modeled atmospheric response to midlatitude SST anomalies and its dependence on background circulation states. J. Climate, 10, 971-987.

Reed, R. J., G. A. Grell, and Y. H. Kuo, 1993: The ERICA IOP 5 Storm. Part II: Sensitivity tests and further diagnosis based on model output. Mon. Wea. Rev., 121, 1595-1612.

Rio, M.-H., and F. Hernandez, 2004: A mean dynamic topography computed over the world ocean from altimetry, in situ measurements, and a geoid model. J. Geophys. Res., 109, C12032, doi:10.1029/2003JC002226.

Rossby, T., and E. Gottlieb, 1998: The Oleander project: Monitoring the variability of the Gulf Stream and adjacent waters between New Jersey and Bermuda. Bull. Amer. Meteor. Soc., 79, $5-18$
Samelson, R. M., E. D. Skyllingstad, D. B. Chelton, S. K. Esbensen, L. W. O'Neill, and N. Thum, 2006: On the coupling of wind stress and sea surface temperature. J. Climate, 19, 15571566.

Sampe, T., and S.-P. Xie, 2007: Mapping high sea winds from space: A global climatology. Bull. Amer. Meteor. Soc., 88, 1965-1978.

— , and _ 2010: Large-scale dynamics of the meiyu-baiu rainband: Environmental forcing by the westerly jet. $\mathrm{J}$. Climate, 23, 113-134.

Sanders, F., 1986: Explosive cyclogenesis over the west-central North Atlantic Ocean, 1981-84. Part I: Composite structure and mean behavior. Mon. Wea. Rev., 114, 1781-1794.

Small, R. J., and Coauthors, 2008: Air-sea interaction over ocean fronts and eddies. Dyn. Atmos. Oceans, 45, 274-319.

Song, Q., P. Cornillon, and T. Hara, 2006: Surface wind response to oceanic fronts. J. Geophys. Res., 111, C12006, doi:10.1029/ 2006JC003680.

Sweet, W., R. Fett, J. Kerling, and P. Laviolette, 1981: Air-sea interaction effects in the lower troposphere across the north wall of the Gulf Stream. Mon. Wea. Rev., 109, 1042-1052.

Tanimoto, Y., H. Nakamura, T. Kagimoto, and S. Yamane, 2003: An active role of extratropical sea surface temperature anomalies in determining anomalous turbulent heat flux. J. Geophys. Res., 108, 3304, doi:10.1029/2002JC001750.

Taylor, A. H., and J. A. Stephens, 1998: The North Atlantic oscillation and the latitude of the Gulf Stream. Tellus, 50A, 134-142.

Thiébaux, J., E. Rogers, W. Wang, and B. Katz, 2003: A new highresolution blended real-time global sea surface temperature analysis. Bull. Amer. Meteor. Soc., 84, 645-656.

Tokinaga, H., Y. Tanimoto, and S.-P. Xie, 2005: SST-induced surface wind variations over the Brazil-Malvinas confluence: Satellite and in situ observations. J. Climate, 18, 3470-3482.

,,--- T. Sampe, H. Tomita, and H. Ichikawa, 2009: Ocean frontal effects on the vertical development of clouds over the western North Pacific: In situ and satellite observations. J. Climate, 22, 4241-4260.

Tomczak, M., and J. S. Godfrey, 2003: Regional Oceanography: An Introduction. 2nd ed. Daya Publishing House, 390 pp.

Trunk, T. J., and L. F. Bosart, 1990: Mean radar echo characteristics during project GALE. Mon. Wea. Rev., 118, 459-469.

Waliser, D. E., N. E. Graham, and C. Gautier, 1993: Comparison of the highly reflective cloud and outgoing longwave radiation datasets for use in estimating tropical deep convection. J. Climate, 6, 331-353.

Wallace, J. M., T. P. Mitchell, and C. Deser, 1989: The influence of sea surface temperature on surface wind in the eastern equatorial Pacific: Seasonal and interannual variability. J. Climate, 2, 1492-1499.

Wang, C., D. B. Enfield, S.-k. Lee, and C. W. Landsea, 2006: Influences of the Atlantic warm pool on Western Hemisphere summer rainfall and Atlantic hurricanes. J. Climate, 19, 30113028.

— S.-k. Lee, and D. B. Enfield, 2007: Impact of the Atlantic warm pool on the summer climate of the Western Hemisphere. J. Climate, 20, 5021-5040.

Warner, T. T., M. N. Lakhtakia, and J. D. Doyle, 1990: Marine atmospheric boundary layer circulations forced by Gulf Stream sea surface temperature gradients. Mon. Wea. Rev., 118, 309-323.

Watanabe, M., F. F. Jin, and J. Pan, 2006: Accelerated iterative method for solving steady problems of linearized atmospheric models. J. Atmos. Sci., 63, 3366-3382. 
White, W. B., and J. L. Annis, 2003: Coupling of extratropical mesoscale eddies in the ocean to westerly winds in the atmospheric boundary layer. J. Phys. Oceanogr., 33, 10951107.

Xie, S.-P., 2004: Satellite observations of cool ocean-atmosphere interaction. Bull. Amer. Meteor. Soc., 85, 195-208.

—, J. Hafner, Y. Tanimoto, W. T. Liu, H. Tokinaga, and H. Xu, 2002: Bathymetric effect on the winter sea surface temperature and climate of the Yellow and East China Seas. Geophys. Res. Lett., 29, 2228, doi:10.1029/2002GL015884.

Young, G. S., and T. D. Sikora, 2003: Mesoscale stratocumulus bands caused by Gulf Stream meanders. Mon. Wea. Rev., 131, 2177-2191.

Zolina, O., and S. K. Gulev, 2003: Synoptic variability of oceanatmosphere turbulent fluxes associated with atmospheric cyclones. J. Climate, 16, 2717-2734. 